\title{
Chevkinite-group minerals in selected intrusions of the Mazury Complex, North-Eastern Poland: insights into the formation of a titanite-like phase by hydrothermal alteration
}

\author{
Justyna Domańska-Siuda ${ }^{1}$ (D) Krzysztof Nejbert $^{1} \cdot$ Bogusław Bagiński $^{1} \cdot$ Ray Macdonald $^{1,2} \cdot$ Jakub Kotowski $^{1}$. \\ Marcin Stachowicz ${ }^{1}$
}

Received: 25 August 2021 / Accepted: 30 December 2021 / Published online: 20 January 2022

(c) The Author(s) 2022

\begin{abstract}
Chevkinite-group minerals forming large and common (up to 0.03 vol\%) accessory phases in monzodiorites and granodiorites from the Mesoproterozoic anorthosite-mangerite-charnockite-granite (AMCG) suite intrusions, Mazury Complex, northeastern Poland, range from pristine magmatic types to hydrothermally altered varieties. The unaltered phase is perrierite-(Ce), with the uncommon feature of having $\mathrm{Al}$ dominant in the $\mathrm{C}$ site. Hydrothermal alteration of the perrierite-(Ce) followed two main trends: one shows depletion in $\mathrm{Ca}, \mathrm{Fe}, \mathrm{Si}, \mathrm{Al}$ and $\mathrm{Mg}$, and increasing Ti contents; the other shows increases in $\mathrm{Si}$, $\mathrm{Ti}$ and $\mathrm{Ca}$ and decreases in light rare-earth elements (LREE), Y and Mg, at about constant Fe content. The second trend resulted in the formation of a phase compositionally similar to titanite. Result of chemical analyses show that the transition from perrierite-(Ce) to the titanite-like phase is sharp; an electron back-scatter diffraction (EBSD) study shows the titanitelike material to be amorphous. The hydrothermal alteration of a chevkinite-group mineral to titanite has commonly been reported in natural sequences but this is the first record of the identification of a titanite-like phase made on the basis of a structural analysis.
\end{abstract}

Keywords AMCG Mazury Complex intrusions · Al-rich perrierite-(Ce) $\cdot$ Hydrothermal alteration $\cdot$ Amorphous titanitelike phase

\section{Introduction}

The chevkinite-group minerals (CGM) are increasingly being recognized as important accessory phases in a wide range of igneous and metamorphic rocks. They are known from hundreds of localities and undoubtedly occur unreported in hundreds more (Macdonald et al. 2019). The group comprises twelve members, the generally accepted formula being $\mathrm{A}_{4} \mathrm{BC}_{2} \mathrm{D}_{2}\left(\mathrm{Si}_{2} \mathrm{O}_{7}\right)_{2} \mathrm{O}_{8}$, where $\mathrm{A}=\mathrm{REE}, \mathrm{Ca}, \mathrm{Sr}$, Th; $\mathrm{B}=\mathrm{Fe}^{2+} ; \mathrm{C}=\mathrm{Fe}^{2+}, \mathrm{Fe}^{3+}, \mathrm{Ti}, \mathrm{Al} ; \mathrm{D}=\mathrm{Ti}$. However, varieties

Editorial handling: L. Nasdala

Justyna Domańska-Siuda

j.domanska@uw.edu.pl

1 Faculty of Geology, Department of Geochemistry, Mineralogy and Petrology, University of Warsaw, ul. Żwirki

i Wigury 93, 02-089 Warsaw, Poland

2 Environment Centre, Lancaster University, Lancaster LA1 4YQ, UK rich in $\mathrm{Zr}, \mathrm{Nb}, \mathrm{Mn}$ and $\mathrm{W}$ are also known. During our ongoing studies of Mesoproterozoic intrusions in NE Poland, we have found CGM which are of particular interest. First, the minerals are unusually large and common and are also texturally very variable. Second, they show the uncommon feature of $\mathrm{Al}$ dominance in the $\mathrm{C}$ site.

Like other REE-bearing accessory minerals, CGM are prone to alteration by hydrothermal fluids. There is a wide range of alteration mechanisms and products, mainly related to the nature of the ligands in the fluids, as reviewed by Macdonald et al. (2019). In the Mazury rocks, we report two modes of hydrothermal alteration, one of them representing an intermediate stage in the breakdown of a CGM to a titanite-like phase, which has been amenable to investigation by electron probe microanalysis (EPMA) and electron backscattered diffraction (EBSD). 


\section{Geological setting}

The rocks studied here have been sampled from three boreholes, Krasnopol PIG-6, Pawłówka PIG-1A, and Filipów IG-1 (Fig. 1) located in the crystalline basement of northeastern Poland. The intrusion are built of rapakivitype granitoids (sensu Haapala et al. 2005) that is are the A-type granites of large batholiths, which include varieties with the rapakivi texture (sensu Vorma 1976; Happala and Rämö 1992; Rämö and Haapala 1995) and associated intermediate and mafic rocks. It belongs to a widespread set of rapakivi-type granitoid intrusions in northern Poland, which together with anorthositic massifs (Suwałki, Sejny and Kętrzyn) form the so-called Mazury Complex (Kubicki and Ryka 1982, 1993). The complex forms a belt of granitoid and associated mafic (anorthositic) and intermediate bodies intruded within the older metamorphic basement of the Eastern European platform and extends over $300 \mathrm{~km}$ from the Baltic Sea (near Elblag in northern Poland) to the Kabeliai and Veisiejai complexes in eastern Lithuania (Skridlaite et al. 2003). The boundaries between individual intrusions in the Mazury Complex in Poland are poorly defined because their structure is based mainly on a few boreholes and geophysical data (Ryka and Sawicki 1980; Kubicki and Ryka 1982; Wybraniec 1999).

Granitoid intrusions of the Mazury Complex are examples of a widespread series of rapakivi granitoids (Happala and Rämö 1992; Rämö and Haapala 1995; Bagiński et al. 2001; Duchesne et al. 2010). These intrusions form massifs of varying sizes, often occurring with anorthosite intrusions, both with features typical of anorogenic magmatism. The crystallization ages of the rapakivi intrusions are in the range 1.81 - $1.47 \mathrm{Ga}$ (Happala and Rämö 1992, 1999; Rämö and Haapala 1995; Shumlyanskyy et al. 2017). The crystallization ages of rapakivi granitoids from the Mazury Complex range from 1548 to $1499 \mathrm{Ma}$, some $50 \mathrm{Ma}$ (Dorr et al. 2002; Wiszniewska et al. 2007). Two samples of quartz monzonite from the Gołdap and Bartoszyce boreholes yielded $\mathrm{U}-\mathrm{Pb}$ zircon ages of $1502 \pm 2 \mathrm{Ma}$ and $1499 \pm 4 \mathrm{Ma}$, respectively (Claesson et al. 1995). The crystallization age of the rapakivi granitoids at Filipów (Fig. 1) is estimated at $1512 \pm 17 \mathrm{Ma}$ based on results of U-Th-Pb zircon SIMS (secondary ion mass spectrometry) analyses (Wiszniewska et al. 2016). The crystallization ages of granites from the Kabeliai and Veisiejai intrusions (in eastern Lithuania) fit the age range of the Mazury Complex, e.g. the 1505 Ma age of the Kabeliai granites in southeastern Lithuania (Sundblad et al. 1994).

The samples studied here come from different depths of the Krasnopol PIG-6, Pawłówka PIG-1A, and Filipów IG-1 boreholes, as listed in Table 1. Compositionally, the rocks straddle the boundary between monzonite and diorite and $\mathrm{SiO}_{2}$ contents range from 56 to $65 \mathrm{wt} \%$. Bagiński et al. (2001), Dörr et al. (2002) and Duchesne et al. (2010) noted that the rocks are metaluminous, with geochemical affinities to A-type suites.
Fig. 1 Geological sketch of the north-eastern part of the crystalline basement in NE Poland (modified after Kubicki and Ryka 1982; Ryka 1982, 1993)
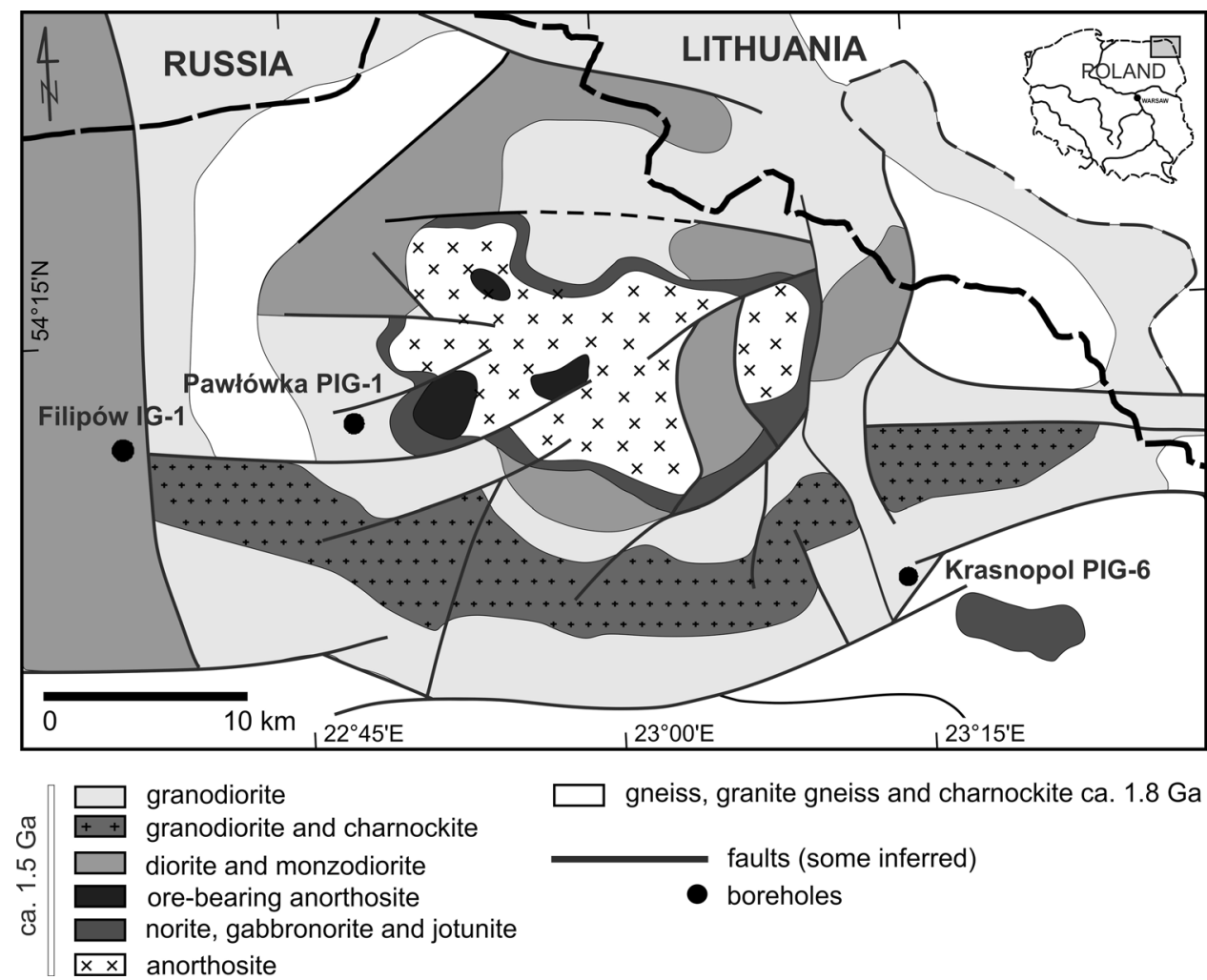

gneiss, granite gneiss and charnockite ca. $1.8 \mathrm{Ga}$

faults (some inferred)

boreholes 


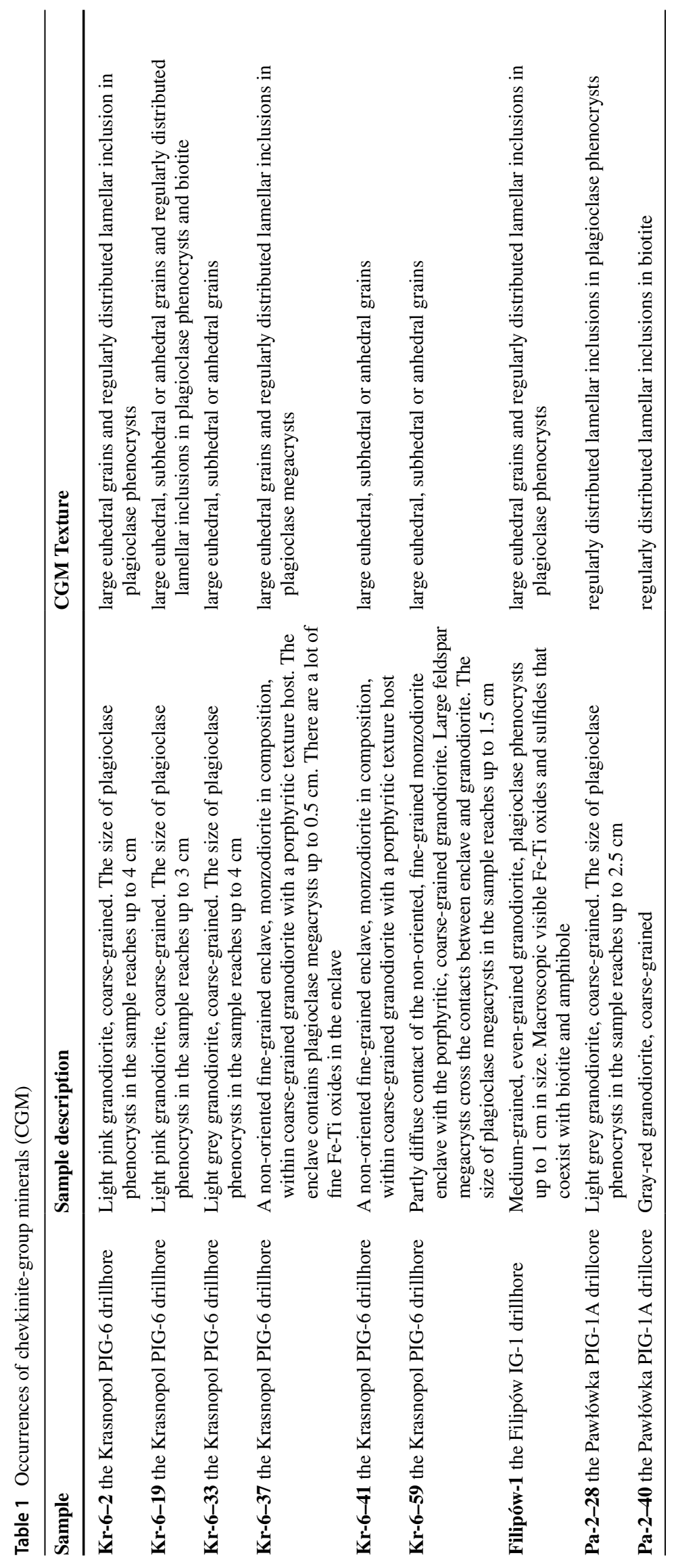


The A/CNK indices [aluminium saturation index: molar ratio of $\left.\mathrm{Al}_{2} \mathrm{O}_{3} /\left(\mathrm{CaO}+\mathrm{Na}_{2} \mathrm{O}+\mathrm{K}_{2} \mathrm{O}\right)\right]$ from Pawłówka PIG$1 \mathrm{~A}$ and Filipów IG-1 are $0.84-0.95$ and $0.82-0.93$, respectively (Bagiński et al. 2001). The rocks from Krasnopol PIG-6 are more diverse, with A/CNK in the range 0.66 -0.93 (Dörr et al. 2002, and our unpublished data). The Mgnumbers [atomic ratio of $100 \times(\mathrm{Mg} /(\mathrm{Mg}+\mathrm{Fe})$ ] are similar and vary in the following ranges: 33 - 35 for Filipów IG-1, 31 - 32 for Pawłówka PIG-1A and 28 - 33 for Krasnopol PIG-6. The $\mathrm{Na}_{2} \mathrm{O} / \mathrm{K}_{2} \mathrm{O}$ ratios are $<1$ and the rocks plot in the high-K field of the Rickwood (1989) diagram (not shown). In the classification of Frost et al. (2001) most samples are alkali-calcic and ferroan.

\section{Analytical methods}

A total of 64 fresh samples were taken from the Krasnopol PIG-6 drill core from a depth range 621 - $1500 \mathrm{~m}$. Chevkinite have also been identified in a few granitoid rock samples taken from the Filipów IG-1 and Pawłówka PIG-1A boreholes. The selection of CGM for microprobe study was performed using reflected-light optical microscopy (NIKON LV100) and electron microscopy with control of the qualitative chemical composition of minerals by means of an energy dispersive spectroscopy (Zeiss Sigma VP equipped with EDS Bruker XFlash 6110 spectrometer). Identification of minerals under the reflected-light microscope was possible due to their large grain sizes (up to $0.5 \mathrm{~mm}$ ), and by clear visible optical properties (reflectance slightly less than $20 \%$ and the presence of visible brown internal reflections).

The chemical compositions of the CGM and alteration products were determined using a CAMECA SX100 EPMA, equipped with four wavelength-dispersion spectrometers.. Operating conditions were as follows: $15 \mathrm{kV}$, beam current $40 \mathrm{nA}$ or $20 \mathrm{nA}$ (for altered grains only), beam-diameter range from 1- $5 \mu \mathrm{m}$ depending on the size of analysed grains, $20 \mathrm{~s}$ and $10 \mathrm{~s}$ counting times for peak and background positions, respectively. Reference materials, selected analytical lines, diffracting crystals, and mean detection limits (quoted in wt\%) were: $\mathrm{Nb}$ (metallic $\mathrm{Nb}, \mathrm{L}_{\mathrm{a}}$, PET, 0.13); Ta (metallic Ta, $\mathrm{M}_{\mathrm{a}}$, TAP, 0.10); $\mathrm{Si}$ (diopside, $\mathrm{K}_{\mathrm{a}}$, TAP, 0.03); Ti (rutile, $\mathrm{K}_{\mathrm{a}}$, PET, 0.06); Zr (zircon, $\mathrm{L}_{\mathrm{a}}$, PET, 0.08); Th $\left(\mathrm{ThO}_{2}, \mathrm{M}_{\mathrm{a}}\right.$, PET, 0.10); U ( $\mathrm{UO}_{2}, \mathrm{M}_{\mathrm{b}}$, PET, 0.10); Al (orthoclase, $\mathrm{K}_{\mathrm{a}}$, TAP, 0.03); $\mathrm{V}\left(\mathrm{V}_{2} \mathrm{O}_{5}, \mathrm{~K}_{\mathrm{a}}\right.$, LIF, 0.15); Sc (metallic Sc, $\mathrm{K}_{\mathrm{a}}$, LPET, 0.02); Y ( $\mathrm{YPO}_{4}, \mathrm{~L}_{\mathrm{a}}$, TAP, 0.12); La (La-glass, $\mathrm{L}_{\mathrm{a}}$, LPET, 0.07); Ce (CeP5O14, L , LPET, 0.08); Pr (Pr-glass, $\mathrm{L}_{\mathrm{b}}$, LIF, 0.35); $\mathrm{Nd}\left(\mathrm{NdGaO}_{3}, \mathrm{~L}_{\mathrm{b}}\right.$, LIF, 0.46); $\mathrm{Sm}\left(\mathrm{SmPO}_{4}\right.$, $\mathrm{L}_{\mathrm{b}}$, LIF, 0.46); $\mathrm{Eu}\left(\mathrm{EuPO}_{4}, \mathrm{~L}_{\mathrm{b}}, \mathrm{LIF}, 0.25\right)$; Gd $\left(\mathrm{GdP}_{5} \mathrm{O}_{14}\right.$, $\mathrm{L}_{\mathrm{b}}$, LIF, 0.49); Mg (diopside, $\mathrm{K}_{\mathrm{a}}$, TAP, 0.03); Ca (diopside, $\mathrm{K}_{\mathrm{a}}$, LPET, 0.02); Mn (rhodonite, $\mathrm{K}_{\mathrm{a}}$, LIF, 0.14), Fe (hematite, $\mathrm{K}_{\mathrm{a}}$, LIF, 0.12), $\mathrm{Sr}$ (celestine, $\mathrm{L}_{\mathrm{a}}$, LPET, 0.16); $\mathrm{Ba}$ (barite, $\mathrm{L}_{\mathrm{a}}$, PET, 0.14); $\mathrm{Pb}$ (crocoite, $\mathrm{M}_{\mathrm{a}}$, PET, 0.22); $\mathrm{Na}$ (albite, $\mathrm{K}_{\mathrm{a}}$, TAP, 0.07); K (orthoclase, $\mathrm{K}_{\mathrm{a}}$, PET, 0.04), and $\mathrm{F}$ (phlogopite, $\mathrm{K}_{\mathrm{a}}$, TAP, 0.81). The spectral interferences of the REE analytical lines were automatically corrected in the quantitative result files by the SX100 software. During the quantification procedure, the interference intensity of the overlapping lines calculated from the measurement on the calibrant material was taken into account. The raw data were reduced using the PAP- $\Phi(\rho Z)$ procedure of Pouchou and Pichoir (1991).

Prior to EBSD examination, the sample was additionally polished (using a vibrating polisher) for $8 \mathrm{~h}$ in a diamond suspension with a grain diameter of $1 / 4 \mu \mathrm{m}$. The sample was covered with a $4.0 \mathrm{~nm}$ carbon layer for better surface discharge. EBSD patterns were collected with a Zeiss Auriga electron microscope equipped with a Brukere-FlashHR + detector with integrated ARGUS imaging device. The sample was tilted to $70^{\circ}$ using the dedicated stage (tilt about sample $\mathrm{X}$ axis) for an optimal EBSD signal with working distance set to $19.15 \mathrm{~mm}$, while the detector tilt angle was $2.42^{\circ}$ and sample to detector distance of $15.02 \mathrm{~mm}$. The experiments were carried out using an electron beam with an energy of $10 \mathrm{kV}$. Image tilt correction was used on the Zeiss SmartSEM software and no image rotation was applied. A single EBSD pattern of $320 \times 240$ resolution was recorded from the $0.86 \times 0.86 \mu \mathrm{m}$ area during $130 \mathrm{~ms}$. The system was calibrated in Bruker ESPRIT 2. The pattern centre (PC), in Bruker fractional coordinates, was measured as: $\mathrm{PC} \mathrm{x}=0.506, \mathrm{PC} \mathrm{y}=0.252$ with a pattern aspect ratio of 1.33 (width/height). The hit rate of indexed pixels was $32.4 \%$; the remaining part of the analysed sample was amorphous.

\section{Results}

\section{Petrography}

\section{The host rocks}

Petrographic descriptions of CMG-bearing samples from the Filipów IG-1 and Pawłówka PIG-1A cores can be found in Bagiński et al. (2001). The Krasnopol PIG-6 core monzodiorites and granodiorites hosting the CGM are coarseand medium-grained with a well-developed porphyritic texture with plagioclase phenocrysts reaching up to $5 \mathrm{~cm}$. The main minerals are plagioclase (An46 - An29), potassium feldspar, quartz, biotite [classified as phlogopite, with $\mathrm{Mg} /\left(\mathrm{Mg}+\mathrm{Fe}_{\text {tot }}\right)$ ratios of $0.52-0.57$ ], amphibole [classified as hastingsite, with $\mathrm{Mg} /\left(\mathrm{Mg}+\mathrm{Fe}_{\text {tot }}\right)$ ratios of $\left.0.57-0.61\right]$, clinopyroxene (classified as diopside, with Wo: 47-51, En: 33-37, Fs:14-19), Fe-Ti oxides and Fe-Cu sulphides (pyrrhotite, pyrite and chalcopyrite). The Krasnopol core is dominated by rocks with high contents of biotite and 
amphibole. Clinopyroxene also occurs over the intervals $1002.8-1308.7$ mand $1380.5-1500 \mathrm{~m}$. The colour of the granitoids is variable; in the upper part of the section it is pink-grey, below the depth of $1112.8 \mathrm{mKrasnopol}$ granitoids lack the pink colour, except at $1263.3-1308.7 \mathrm{~m}$, where the granitoids are again reddish.

A notable feature of the rocks is the presence of finegrained enclaves. These are usually dark in colour. The overall size and form of the enclaves are difficult to define due to the fact that the rocks come from drill core; however, they commonly occur with monzodiorite/granodiorite at various depths. Compositionally they are monzonite, monzodiorite or monzogabbro. Usually they show non-oriented textures, are equigranular and occasionally contain large (up to $3 \mathrm{~cm}$ ) K-feldspar or/and plagioclase (up to $0.5 \mathrm{~cm}$ ) megacrysts. Sometimes they show a magmatic foliation, defined by mafic minerals. Enclaves are composed of the same minerals as the surrounding rocks, differing only in their greater abundance of plagioclase and mafic minerals. The chemical composition of enclave minerals is also similar to that of the host rock. The rocks matrix consist of 35-45 vol\% plagioclase $\left(\mathrm{An}_{48-24}\right), 20-30$ vol\% phlogopite, with $\mathrm{Mg} /$ $\left(\mathrm{Mg}+\mathrm{Fe}_{\text {tot }}\right)$ ratios of $0.53-0.64,0-30 \mathrm{vol} \%$ clinopyroxene diopside, with Wo: 43-51; En: 33-37; Fs: 12-23 and 0-25 vol\% hastingsite, with $\mathrm{Mg} /\left(\mathrm{Mg}+\mathrm{Fe}_{\text {tot }}\right)$ ratios of $0.56-0.63$. Quartz and K-feldspar are interstitial and subordinate. Common accessory minerals are magnetite and ilmenite, apatite, zircon and titanite.

The contacts of the enclaves with granodiorite are partly diffuse, lobate to crenulate. Large feldspar megacrysts are observed to cross the contacts between enclave and granodiorite, in addition to occurring inside them. The plagioclase phenocrysts show poikilitic rims with mainly clinopyroxene and ilmenite inclusions. K-feldspar phenocrysts also have poikilitic rims with inclusions of plagioclase, clinopyroxene, biotite, apatite and ilmenite. The textural relationships are consistent with the mixing/mingling of two melts of different composition. Sample details are given in Table 1.

\section{Chevkinite-group minerals}

The CGM are common in samples of monzodiorites and granodiorites from Krasnopol PIG-6 drillcore (Nejbert et al. 2020). From 3 to 7 grains with a diameter of more than $100 \mu \mathrm{m}$ were identified in a standard $6 \mathrm{~cm}^{2}$ thin section. In addition, numerous small CGM inclusions, with sizes well below $10 \mu \mathrm{m}$, were observed within feldspars and biotite. The number of such inclusions is difficult to estimate; generally during the study of standard thin sections, from 20 to 30 such grains were identified using scanning electron microscopy-energy dispersive X-ray spectroscopy (SEM-EDS) methods. In samples identified as the richest in CMG, and/ or titanite-like phases formed after this mineral, they may constitute a maximum up to $0.03 \mathrm{vol} \%$. The CGM are present in a wide variety of forms but the two most common are prismatic and platy. The prismatic types are usually between 50 and $100 \mu \mathrm{m}$ long, which in our experience is unusually large for CGM (other than in pegmatites). They are bright [high average atomic number $(\bar{Z})$ contrast] on backscattered electrons (BSE) images and fairly homogeneous (Fig. 2a, b). The crystal in Fig. 2a is enclosed in magnetite showing ilmenite exsolution lamellae, those in Fig. $2 \mathrm{~b}$ in alkali feldspar, evidence that they were of magmatic crystallization. The spear-shaped crystal shown in Fig. 2c is patchily zoned, with high- $\bar{Z}$ material forming a residual part of the core and an extreme tip. The platy types are larger, up to $500 \mu \mathrm{m}$ across, and usually patchily zoned from bright to vary dark. The crystal shown in Fig. 2d is unusual in being bright, but with a small, low $\bar{Z}$, core area and a dark rim which is associated with a patchily zoned grain. The core of the subhedral crystal in Fig. 2e is very complex and patchy, with a higher $\bar{Z}$ mantle where oscillatory zoning is just visible. The patchy core is more metamict than the rim due to a higher content of Th. The patchily zoned CGM at the left-hand edge of the crystal in Fig. 2f has been replaced towards the rims by an aggregate of a REE carbonate.

Textural features typical of magmatic crystallization are preserved in some crystals, such as the subhedral-euhedral form of certain prismatic crystals (Fig. 2a, b), crystals intergrown with magmatic minerals (Fig. 2a, b), and those which display oscillatory zoning (Fig. 2e). Mainly, however, magmatic zoning has been overprinted by hydrothermal alteration, recognizable by the development of patchy zones of lower $\bar{Z}$, as opposed to unaltered crystals which are invariably bright (high $\bar{Z})$ on BSE images.

The question arises as to why the degree of alteration was so variable, even within single thin sections. It seems that the unaltered crystals were protected by being enclosed within plagioclase crystals, e.g. in Fig. 2b. In contrast, the altered grains tended to occur along intergranular boundaries and were presumably involved in extensive intergranular fluid flow.

The CGM were also identified in granitoid samples from the Filipów IG-1 and Pawłówka PIG-1A boreholes. These occurred as large grains (up to about $100 \mu \mathrm{m}$ ), associated with $\mathrm{Fe}$-Ti oxide aggregates and pyrrhotite, and fine, up to $10 \mu \mathrm{m}$, lamellar perrierite-(Ce) crystals appearing as fine, regularly distributed inclusions in plagioclase. In several large plagioclase crystals, a parallel arrangement of fine perrierite grains was observed, which were also arranged parallel to the fine Fe-Ti oxides. In the samples from the Filipów IG-1 and Pawłówka PIG-1A boreholes, all the larger CGM grains were highly altered and broken down into titanite-like phases, allanite, REE-fluorocarbonates, and $\mathrm{Ca}-\mathrm{Fe}$ carbonates. Only the small-sized lamellar perrierite-(Ce) inclusions 
Fig. 2 Selection of representative BSE images of CGM-containing specimens. a Prismatic perrierite-(Ce) (Prr-Ce) intergrown with magnetite (Mag) showing ilmenite exsolution lamellae (Ilm). Sample Kr-633; analyses 1-10 in Table S1, Kr-6-33. b Prismatic perrierite-(Ce) embedded in alkali feldspar (Afs). Sample Fil-1, analyses in Table S2, Filipów 1. c Spear-shaped perrierite-(Ce) with patchy alteration (aPrr), sample $\mathrm{Kr}-6-41$, analyses in Table S2, Kr-6-41. Ap - apatite. d Anhedral perrierite-(Ce) with dark altered core and rim, associated in the bottom part with a patchily zoned grain. Sample Kr-6-41, analyses 1-12 in Table S2, Kr-6-41. e Subhedral perrierite-(Ce) with oscillatory zoning and patchy core. Sample Kr-6-41, analyses 14-26 in Table S2. f The patchily zoned perrierite-(Ce) replaced towards the rims by an aggregate of a REE-carbonate (REE-Cb). Sample Pawłówka PIG-1A
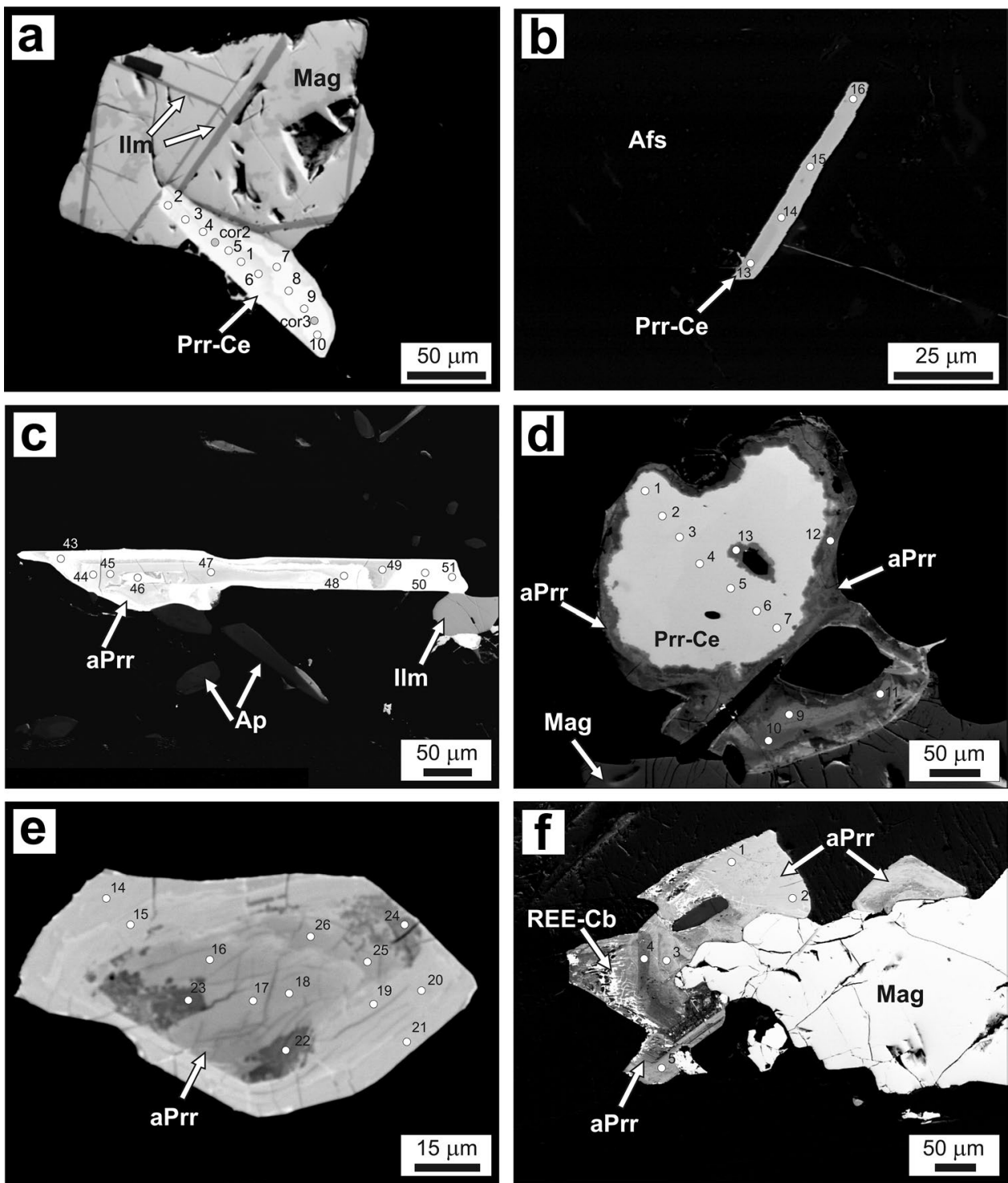

within plagioclase were relatively poorly altered as shown by their high brightness on the BSE images.

\section{Composition of CGM}

\section{Perrierite-(Ce) compositions}

Representative compositions of unaltered perrierite-(Ce) are given in Table 2; the full data set is given in Tables S1-S3 in the electronic supplementary material (ESM). Fluorine has been reported in the CGM, at levels up to $5.31 \mathrm{wt} \%$. Belkin et al. (2009) argued that the F values determined by EPMA represent interference between the F- $K \alpha(\lambda=18.3199 \AA)$ and $\mathrm{Ce}-M \xi(\lambda=18.3499 \AA)$ peaks. This, plus the uncertainty as to where F may be incorporated in the CGM structure, has resulted in the F values being reported in Tables S1-S3 but not included in formula calculations. On the $\mathrm{FeO}^{*}$ versus $(\mathrm{CaO}+\mathrm{SrO})$ (with $\mathrm{FeO}^{*}=$ total $\mathrm{Fe}$ expressed as $\left.\mathrm{FeO}\right)$ discrimination plot (Macdonald et al. 2009), they fall in the perrierite field (Fig. 3), with crystals from Filipów-1 showing slightly higher $(\mathrm{CaO}+\mathrm{SrO})$ values than those from Krasnopol PIG-6. Compositionally, they usually have analytical totals $>95 \mathrm{wt} \%$ and are close to the stoichiometric formula $\mathrm{A}_{4} \mathrm{BC}_{2} \mathrm{Ti}_{2}\left(\mathrm{Si}_{2} \mathrm{O}_{7}\right)_{2} \mathrm{O}_{8}$. Cations have been allocated to structural sites as follows: A-REE, Ca, Y, Sr, Th, B- $\mathrm{Fe}^{2+}$, $\mathrm{C}-\mathrm{Fe}^{2+}, \mathrm{Mn}, \mathrm{Mg}, \mathrm{Al}, \mathrm{V}, \mathrm{Sc}, \mathrm{Zr}, \mathrm{Nb}, \mathrm{Ta}, \mathrm{Ti}$; D-Ti; T-Si. Recent work has shown that in some CGM cations may not enter the standard structural sites. For example, Stachowicz et al. (2019) allocated some $\mathrm{Nb}$ and $\mathrm{Mg}$ to the $\mathrm{D}$ site in their study of Nb-rich chevkinite- $(\mathrm{Ce})$ from the Biraya rare-metal deposit, Russia, and Nagashima et al. (2020) allocated some Th to the B (M1) site in chevkinite-(Ce) from Ashizuri, Japan. However, in the current case the allocations result in 
Table 2 Representative chemical compositions and calculated mineral formulae of unaltered perrierite-(Ce)

\begin{tabular}{|c|c|c|c|c|c|c|c|c|}
\hline Sample & Kr-6-59 & Kr-6-59 & Kr-6-59 & Kr-6-41 & Kr-6-41 & Kr-6-41 & Kr-6-33 & Kr-6-2 \\
\hline Analysis & 1 & 2 & 3 & 4 & 5 & 6 & 7 & 8 \\
\hline \multicolumn{9}{|c|}{ Major constituents (wt\%) } \\
\hline $\mathrm{Nb}_{2} \mathrm{O}_{5}$ & 0.08 & bdl & 0.09 & bdl & bdl & bdl & bdl & bdl \\
\hline $\mathrm{Ta}_{2} \mathrm{O}_{5}$ & 0.09 & 0.19 & 0.08 & 0.15 & 0.15 & bdl & 0.12 & 0.08 \\
\hline $\mathrm{SiO}_{2}$ & 20.69 & 20.64 & 20.34 & 20.52 & 20.19 & 20.85 & 20.55 & 20.70 \\
\hline $\mathrm{TiO}_{2}$ & 17.66 & 17.77 & 18.28 & 18.12 & 18.50 & 18.99 & 17.89 & 18.58 \\
\hline $\mathrm{ZrO}_{2}$ & 0.59 & 0.61 & 0.51 & 0.70 & 0.49 & 0.98 & 0.41 & 1.54 \\
\hline $\mathrm{ThO}_{2}$ & 2.17 & 2.86 & 0.34 & 2.52 & 0.10 & 0.08 & 1.37 & 1.54 \\
\hline $\mathrm{Al}_{2} \mathrm{O}_{3}$ & 3.80 & 3.86 & 3.83 & 3.81 & 3.90 & 3.79 & 4.02 & 4.12 \\
\hline $\mathrm{V}_{2} \mathrm{O}_{3}$ & 0.15 & 0.12 & 0.19 & 0.32 & 0.15 & 0.18 & 0.11 & 0.15 \\
\hline $\mathrm{Sc}_{2} \mathrm{O}_{3}$ & 0.29 & 0.27 & 0.45 & 0.23 & 0.40 & 0.38 & 0.37 & 0.39 \\
\hline $\mathrm{Y}_{2} \mathrm{O}_{3}$ & 0.31 & 0.30 & 0.26 & 0.26 & 0.30 & 0.34 & 0.35 & 0.29 \\
\hline $\mathrm{La}_{2} \mathrm{O}_{3}$ & 10.05 & 10.03 & 9.84 & 9.93 & 9.83 & 9.70 & 10.97 & 9.34 \\
\hline $\mathrm{Ce}_{2} \mathrm{O}_{3}$ & 19.18 & 18.99 & 19.28 & 19.12 & 19.32 & 19.08 & 20.08 & 17.16 \\
\hline $\mathrm{Pr}_{2} \mathrm{O}_{3}$ & 1.44 & 1.41 & 1.69 & 1.37 & 1.68 & 1.49 & 1.57 & 1.46 \\
\hline $\mathrm{Nd}_{2} \mathrm{O}_{3}$ & 5.68 & 5.97 & 5.75 & 5.29 & 5.82 & 5.61 & 6.29 & 5.51 \\
\hline $\mathrm{Sm}_{2} \mathrm{O}_{3}$ & 0.45 & 0.39 & 0.26 & 0.27 & 0.51 & 0.60 & 0.48 & 0.44 \\
\hline $\mathrm{Eu}_{2} \mathrm{O}_{3}$ & 0.56 & 0.44 & 0.52 & 0.48 & 0.62 & 0.54 & - & 0.40 \\
\hline $\mathrm{Gd}_{2} \mathrm{O}_{3}$ & 0.24 & 0.24 & bdl & bdl & 0.36 & 0.28 & bdl & 0.24 \\
\hline $\mathrm{MgO}$ & 0.68 & 0.75 & 0.61 & 0.66 & 0.61 & 0.49 & 0.80 & 0.51 \\
\hline $\mathrm{CaO}$ & 5.21 & 5.18 & 5.18 & 5.22 & 5.34 & 5.44 & 4.91 & 5.99 \\
\hline $\mathrm{MnO}$ & bdl & 0.08 & bdl & bdl & bdl & bdl & 0.10 & bdl \\
\hline $\mathrm{FeO}^{*}$ & 6.90 & 7.18 & 6.95 & 7.12 & 7.18 & 6.51 & 6.91 & 6.43 \\
\hline $\mathrm{SrO}$ & 0.10 & - & 0.03 & - & - & - & - & - \\
\hline $\mathrm{BaO}$ & bdl & bdl & 0.17 & bdl & bdl & bdl & - & 0.21 \\
\hline $\mathrm{F}$ & bdl & bdl & bdl & bdl & bdl & bdl & bdl & bdl \\
\hline Sum & 96.32 & 97.28 & 94.65 & 96.09 & 95.45 & 95.33 & 97.30 & 95.08 \\
\hline$\Sigma \mathrm{REE}_{2} \mathrm{O}_{3}$ & 37.60 & 37.47 & 37.32 & 36.46 & 38.14 & 37.30 & 39.38 & 34.55 \\
\hline \multicolumn{9}{|c|}{ Calculated formulae (apfu)* } \\
\hline $\mathrm{Ca}$ & 1.115 & 1.103 & 1.115 & 1.115 & 1.141 & 1.147 & 1.043 & 1.268 \\
\hline $\mathrm{Sr}$ & 0.012 & - & 0.004 & - & - & - & - & - \\
\hline $\mathrm{Ba}$ & 0.000 & 0.000 & 0.014 & 0.000 & 0.000 & 0.000 & 0.000 & 0.016 \\
\hline $\mathrm{Y}$ & 0.033 & 0.032 & 0.028 & 0.027 & 0.032 & 0.036 & 0.037 & 0.031 \\
\hline $\mathrm{La}$ & 0.741 & 0.735 & 0.729 & 0.730 & 0.723 & 0.704 & 0.801 & 0.681 \\
\hline $\mathrm{Ce}$ & 1.403 & 1.381 & 1.418 & 1.396 & 1.411 & 1.375 & 1.457 & 1.242 \\
\hline $\operatorname{Pr}$ & 0.105 & 0.102 & 0.123 & 0.100 & 0.122 & 0.107 & 0.113 & 0.105 \\
\hline $\mathrm{Nd}$ & 0.405 & 0.424 & 0.412 & 0.376 & 0.414 & 0.394 & 0.445 & 0.389 \\
\hline $\mathrm{Sm}$ & 0.031 & 0.027 & 0.018 & 0.018 & 0.035 & 0.041 & 0.033 & 0.030 \\
\hline $\mathrm{Eu}$ & 0.038 & 0.030 & 0.036 & 0.033 & 0.042 & 0.036 & 0.000 & 0.027 \\
\hline $\mathrm{Gd}$ & 0.016 & 0.016 & 0.000 & 0.000 & 0.024 & 0.018 & 0.000 & 0.016 \\
\hline Th & 0.099 & 0.129 & 0.015 & 0.114 & 0.005 & 0.004 & 0.062 & 0.069 \\
\hline Sum A & 3.996 & 3.978 & 3.911 & 3.910 & 3.948 & 3.861 & 3.991 & 3.874 \\
\hline $\mathrm{Fe}^{2+}(=\mathrm{B})$ & 1.000 & 1.000 & 1.000 & 1.000 & 1.000 & 1.000 & 1.000 & 1.000 \\
\hline $\mathrm{Fe}^{2+}$ & 0.153 & 0.193 & 0.167 & 0.187 & 0.197 & 0.071 & 0.145 & 0.063 \\
\hline $\mathrm{Mn}$ & 0.000 & 0.013 & 0.000 & 0.000 & 0.000 & 0.000 & 0.016 & 0.000 \\
\hline $\mathrm{Mg}$ & 0.203 & 0.221 & 0.183 & 0.196 & 0.181 & 0.144 & 0.237 & 0.151 \\
\hline $\mathrm{Al}$ & 0.895 & 0.903 & 0.906 & 0.894 & 0.917 & 0.879 & 0.939 & 0.960 \\
\hline V & 0.023 & 0.019 & 0.031 & 0.052 & 0.024 & 0.028 & 0.018 & 0.024 \\
\hline Sc & 0.050 & 0.047 & 0.079 & 0.040 & 0.069 & 0.065 & 0.064 & 0.067 \\
\hline $\mathrm{Zr}$ & 0.057 & 0.059 & 0.050 & 0.000 & 0.048 & 0.094 & 0.040 & 0.148 \\
\hline $\mathrm{Nb}$ & 0.008 & 0.000 & 0.008 & 0.068 & 0.000 & 0.000 & 0.003 & 0.000 \\
\hline
\end{tabular}


Table 2 (continued)

\begin{tabular}{lllllllll}
\hline $\begin{array}{l}\text { Sample } \\
\text { Analysis }\end{array}$ & $\begin{array}{l}\text { Kr-6-59 } \\
1\end{array}$ & $\begin{array}{l}\text { Kr-6-59 } \\
2\end{array}$ & $\begin{array}{l}\text { Kr-6-59 } \\
3\end{array}$ & $\begin{array}{l}\text { Kr-6-41 } \\
4\end{array}$ & $\begin{array}{l}\text { Kr-6-41 } \\
5\end{array}$ & $\begin{array}{l}\text { Kr-6-41 } \\
6\end{array}$ & $\begin{array}{l}\text { Kr-6-33 } \\
7\end{array}$ & $\begin{array}{l}\text { Kr-6-2 } \\
8\end{array}$ \\
\hline $\mathrm{Ta}$ & 0.057 & 0.059 & 0.050 & 0.008 & 0.008 & 0.000 & 0.007 & 0.002 \\
$\mathrm{Ti}$ & 0.654 & 0.654 & 0.761 & 0.718 & 0.774 & 0.810 & 0.665 & 0.761 \\
$\mathrm{Sum} \mathrm{C}$ & 2.100 & 2.169 & 2.235 & 2.162 & 2.218 & 2.091 & 2.133 & 2.176 \\
$\mathrm{Ti}(=\mathrm{D})$ & 2.000 & 2.000 & 2.000 & 2.000 & 2.000 & 2.000 & 2.000 & 2.000 \\
$\mathrm{Si}(=\mathrm{D})$ & 4.132 & 4.099 & 4.085 & 4.091 & 4.026 & 4.102 & 4.071 & 4.092 \\
$\Sigma$ cations & 13.23 & 13.25 & 13.23 & 13.16 & 13.18 & 13.05 & 13.23 & 13.14 \\
\hline
\end{tabular}

*Calculated based on $22 \mathrm{O}$ atoms per formula unit. $\mathrm{Na}_{2} \mathrm{O}, \mathrm{K}_{2} \mathrm{O}$ and $\mathrm{PbO}$ below detection in all samples. $\mathrm{FeO}^{*}$, all $\mathrm{Fe}$ as $\mathrm{Fe}^{2+}$. Dash—not determined. bdl, below detection limit

near-stoichiometric formulae: A-3.85 - 4.0 (average 3.9) apfu; B-1.0 apfu; C $-2.0-2.25$ (2.15) apfu; D-2.0 apfu, $\mathrm{Si}-4.1-4.15(4.1)$ apfu and cation sums are in the range $13.1-13.25$ (13.2) apfu. It may be inferred that the cation allocations are a fair representation of their distribution in the natural minerals.

Variations in the abundances of the major components are modest, e.g. $\mathrm{SiO}_{2} 20.2-20.9 \mathrm{wt} \%, \mathrm{TiO}_{2} 17.7-19.0$ wt $\%$ and $\mathrm{Ce}_{2} \mathrm{O}_{3} 17.2-20.1 \mathrm{wt} \%$. Those in the minor components are larger, e.g. $\mathrm{ThO}_{2} 0.1-2.9 \mathrm{wt} \%$ and $\mathrm{ZrO}_{2} 0.4$ $-1.5 \mathrm{wt} \%$. The exceptionally high values of $\mathrm{ThO}_{2}$ in a crystal in sample Kr-6-33, $\leq 9.10 \mathrm{wt} \%$ (Table S1; Fig. 2a), match those in perrierite-(Ce) from the rhyolitic Joe Lott

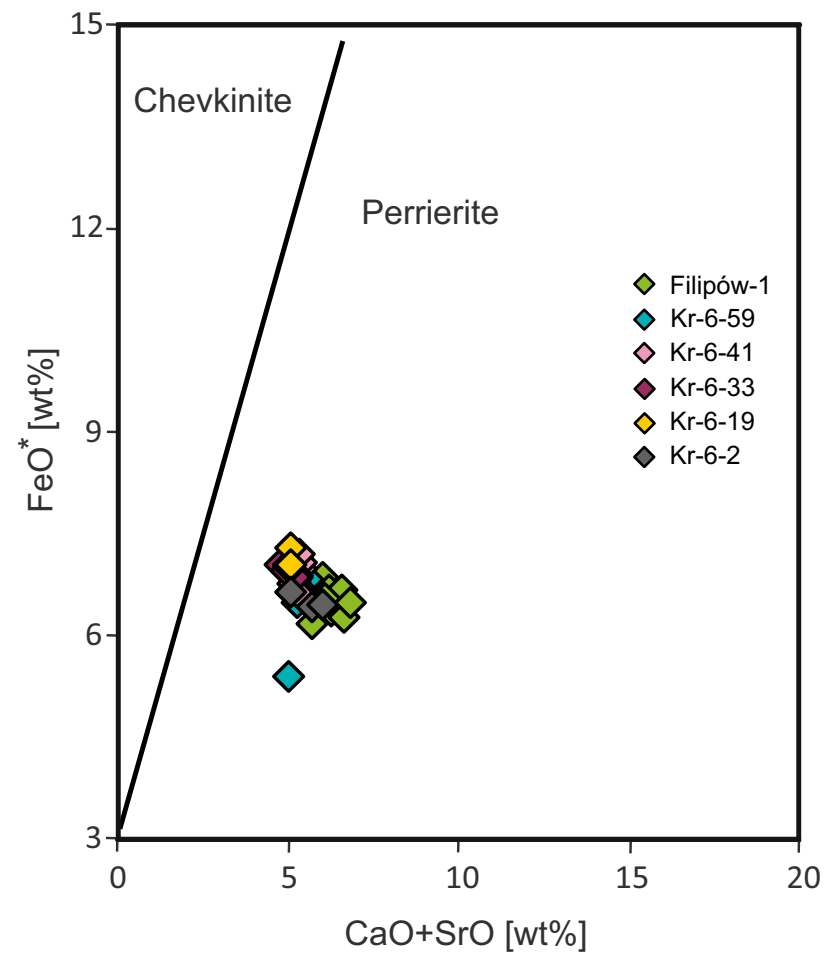

Fig. 3 Composition of unaltered CGM plotted in the discrimination plot of Macdonald et al. (2009). Data from Tables S1-S3
Tuff, Utah (Galanciak et al. 2020) in being among the highest yet recorded in the CGM. An important feature is that $\mathrm{Al}$ is the dominant cation in the $\mathrm{C}$ site. This feature has previously been recorded in perrierite in high-grade metamorphic rocks from Antarctica and India (Harley 1994; Hokada 2007; Belkin et al. 2009), and in chevkinite in albitites from Siberia (Proschenko 1967) and the Pyrenees (Monchoux et al. 2006) (Fig. 4).

Chondrite-normalized REE plots (Fig. 5) show decreases from $\mathrm{La}$ to $\mathrm{Sm}$, with a significant variation in $\mathrm{La}_{\mathrm{N}} / \mathrm{Sm}_{\mathrm{N}}$ values $(6-24)$, and strong positive Eu anomalies $\left(\mathrm{Eu} / \mathrm{Eu}^{*} 1.7\right.$ -5.1 , with two outliers at 9.5 and 10.8). However, the ranges may partly reflect $\mathrm{Sm}$, Eu and Gd values close to the EPM detection limits. Positive Eu anomalies might be a result of plagioclase breakdown during the observed sericitisation process (Zozulya et al. 2020).

\section{Hydrothermal alteration trends}

Compositions of altered CGM are given in Table 3 and Tables S1-S3. Previous studies of the hydrothermal alteration of CGM, summarized in Bagiński et al. (2015) and Macdonald et al. (2019) have shown that invariable compositional features of the process are low analytical totals and non-stoichiometric formulae. These features also mark the Mazury Complex CGM. Analytical totals are always less than $95 \mathrm{wt} \%$ and as low as $85 \mathrm{wt} \%$, the low values presumably reflecting water absorbed into the structure and/ or the presence of vacancies. Sums of cations are as low as $12.2 \mathrm{apfu}$. Data for altered crystals initially follow a trend of decreasing $\mathrm{Fe}$ contents at about constant $\mathrm{Ca}$ content until at $3 \mathrm{wt} \% \mathrm{CaO}$ they diverge into two trends. One, an initial $\mathrm{Fe}$-depletion trend, varies between specimens; in $\mathrm{Kr}-6-41$, for example, a slight increase in $\mathrm{CaO}$ reverses at $\mathrm{FeO}^{*} 4.5 \mathrm{wt} \%$, followed by rapid $\mathrm{Fe}$ and $\mathrm{Ca}$ depletion to $<2 \mathrm{wt} \% \mathrm{CaO}$, while in Filipów-1, the earliest alteration phase resulted in $\mathrm{Ca}$ depletion before the trend involved strong depletion in $\mathrm{Ca}$ and $\mathrm{Fe}$ to $\sim 2 \mathrm{wt} \% \mathrm{CaO}$ (Fig. 6a). Other features of this part of the trend include decreases in $\mathrm{Si}, \mathrm{Al}$ and $\mathrm{Mg}$ contents and increasing Ti. In Kr-6-41 REE 
Fig. 4 Plot of Ti-Fe ${ }^{2+}-\mathrm{Al}$ in $\mathrm{C}$ site of unaltered crystals, showing the dominance of $\mathrm{Al}$. Data from Tables S1-S3. Perrierites from granulites from India and Antarctica plotted for comparison (Belkin et al. 2009, Table 1). Values are plotted in apfu
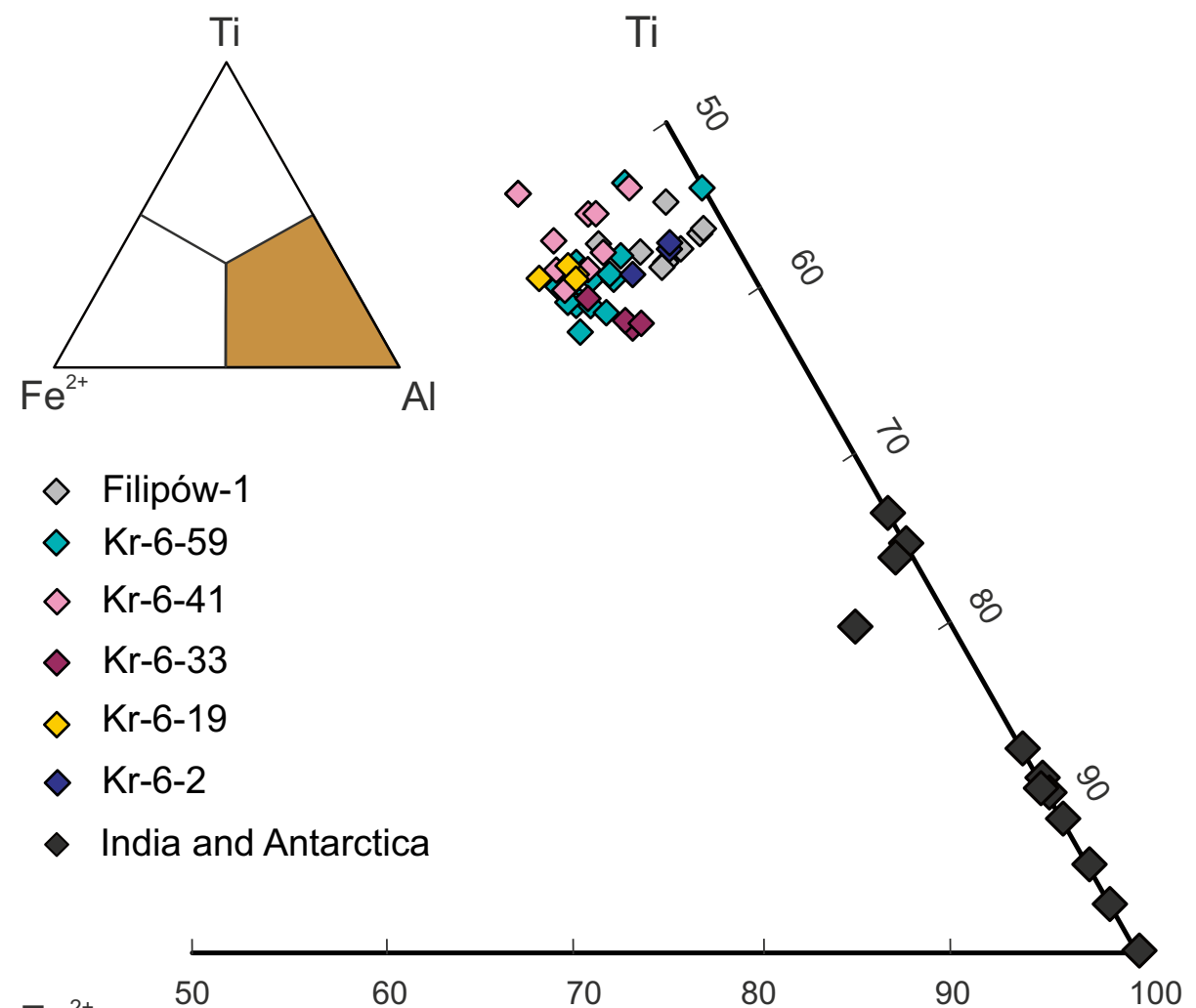

60
$\mathrm{Fe}^{2+}$

50 abundances decrease along the trend, whereas in Filipów-2, REE increase along it.

The main feature of compositions along the second trend is the increasing contents of $\mathrm{Ti}, \mathrm{Ca}$ (Fig. $6 \mathrm{~b}$ ) and $\mathrm{Si}$ at about constant $\mathrm{Fe}$. Other features are the increasing $\mathrm{Al}$ and decreasing contents of REE, Y, Mg, Sc and Zr. The $\mathrm{REE}_{2} \mathrm{O}_{3}$ contents, for example, which total $36-38 \mathrm{wt} \%$ in the unaltered CGM, are $<5 \mathrm{wt} \%$ in the most altered samples: this is discussed in more detail below.

There are minor variants on the alteration schemes described above. For example, in Kr-6-19 two low Ti-Ca

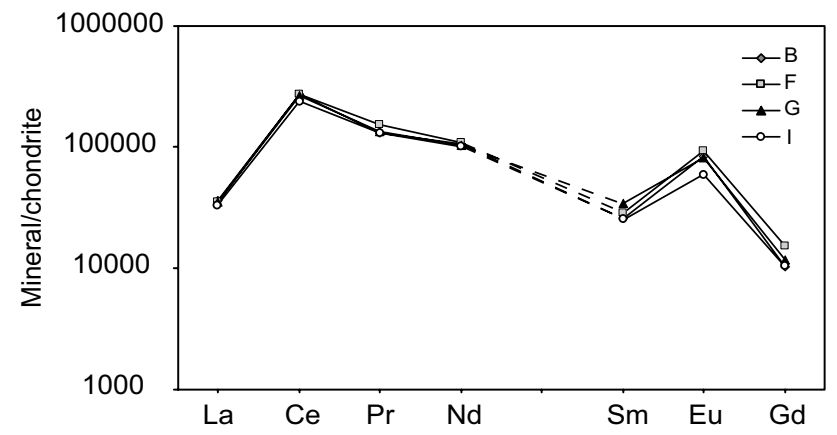

Fig. 5 Chondrite-normalized REE plots for representative unaltered perrierite-(Ce). Data from Table 2. Normalizing factors after Sun and McDonough (1989) analyses (Table 3 and S1; analyses 53,54) have high $\mathrm{Fe}\left(12.61,11.21 \mathrm{wt} \% \mathrm{FeO}^{*}\right)$ and low REE (20.08 wt\% $\mathrm{REE}_{2} \mathrm{O}_{3}$ ). In Fig. $6 \mathrm{a}$, b for unusually Fe-rich altered analyses plot with the unaltered types (arrowed). Two other low Ti-Ca analyses $(30,34)$ have low $\mathrm{Fe}(0.90,0.93 \mathrm{wt} \% \mathrm{FeO} *)$ and high REE (44.62, $\left.48.96 \mathrm{wt} \% \mathrm{REE}_{2} \mathrm{O}_{3}\right)$. All these analyses have high $\mathrm{F}$ contents $(2-5 \mathrm{wt} \%)$ and it is possible that this has resulted in some unusual element redistribution. Alternatively, the compositional features may be related to the nature of other accessory minerals forming during the alteration.

Extrapolation of $\mathrm{Ti}, \mathrm{Si}$ and $\mathrm{Ca}$ values in the second trend coincide with the composition of titanite (Fig. 6b). The two analyses closest to titanite are from Kr-6-19 (Table S1; analyses 63,64$)$. The average formula, calculated on the basis of 5 oxygens, is $\left[\mathrm{Ca}_{0.88} \Sigma(\mathrm{La}-\mathrm{Nd})_{0.04} \mathrm{Sr}_{0.02}\right)_{0.94}$ $\left(\mathrm{Ti}_{0.75} \mathrm{Al}_{0.20} \mathrm{Fe}^{2+}{ }_{0.03}\right)_{0.98} \mathrm{Si}_{1.09}$, with the sum of cations $=3.04$, i.e. the phase is compositionally close to titanite, $\mathrm{CaTiOSiO}_{4}$, with some replacement of Ti by Al. The $\mathrm{Al}$ levels are significant $\left(\leq 5 \mathrm{wt} \% \mathrm{Al}_{2} \mathrm{O}_{3}\right)$ but not exceptional: Seifert and Kramer (2003), for example, recorded values of $\mathrm{Al}_{2} \mathrm{O}_{3}$ up to $\sim 15 \mathrm{wt} \%$ in titanite from lamprophyres of the Variscan orogeny in Germany. In comparison, Jiang et al. (2006) reported $3.99 \mathrm{wt} \% \mathrm{Al}_{2} \mathrm{O}_{3}$ in titanite in an allaniteilmenite-titanite mantle on altered chevkinite-(Ce) in the Shuiquangou syenite, China. Additionally Vlach et al. 
Table 3 Representative compositions of altered CMG

\begin{tabular}{|c|c|c|c|c|}
\hline Sample & Kr-6-19 & Kr-6-19 & Kr-6-19 & Kr-6-19 \\
\hline Analysis & 53 & 54 & 63 & 64 \\
\hline \multicolumn{5}{|c|}{ Major constituents (wt\%) } \\
\hline $\mathrm{Nb}_{2} \mathrm{O}_{5}$ & bdl & bdl & bdl & bdl \\
\hline $\mathrm{Ta}_{2} \mathrm{O}_{5}$ & 0.15 & 0.12 & bdl & bdl \\
\hline $\mathrm{SiO}_{2}$ & 26.73 & 25.78 & 31.66 & 31.70 \\
\hline $\mathrm{TiO}_{2}$ & 15.28 & 14.53 & 29.19 & 28.69 \\
\hline $\mathrm{ZrO}_{2}$ & 1.18 & 1.15 & 0.31 & 0.40 \\
\hline $\mathrm{ThO}_{2}$ & 0.56 & 0.61 & 0.31 & 0.33 \\
\hline $\mathrm{Al}_{2} \mathrm{O}_{3}$ & 4.16 & 3.41 & 4.90 & 5.02 \\
\hline $\mathrm{V}_{2} \mathrm{O}_{3}$ & 0.33 & 0.23 & 0.16 & 0.24 \\
\hline $\mathrm{Sc}_{2} \mathrm{O}_{3}$ & 1.48 & 1.55 & 0.16 & 0.19 \\
\hline $\mathrm{Y}_{2} \mathrm{O}_{3}$ & bdl & bdl & bdl & bdl \\
\hline $\mathrm{La}_{2} \mathrm{O}_{3}$ & 4.76 & 5.07 & 0.20 & 0.35 \\
\hline $\mathrm{Ce}_{2} \mathrm{O}_{3}$ & 10.79 & 11.93 & 1.70 & 1.86 \\
\hline $\mathrm{Pr}_{2} \mathrm{O}_{3}$ & 0.98 & 0.85 & 0.16 & 0.22 \\
\hline $\mathrm{Nd}_{2} \mathrm{O}_{3}$ & 2.96 & 3.82 & 0.53 & 0.84 \\
\hline $\mathrm{Sm}_{2} \mathrm{O}_{3}$ & 0.28 & 0.32 & bdl & bdl \\
\hline $\mathrm{Eu}_{2} \mathrm{O}_{3}$ & bdl & bdl & bdl & bdl \\
\hline $\mathrm{Gd}_{2} \mathrm{O}_{3}$ & 0.30 & bdl & bdl & bdl \\
\hline $\mathrm{MgO}$ & 1.67 & 1.39 & 0.02 & 0.02 \\
\hline $\mathrm{CaO}$ & 5.67 & 7.57 & 23.85 & 23.95 \\
\hline $\mathrm{MnO}$ & 0.44 & 0.48 & bdl & bdl \\
\hline $\mathrm{FeO} *$ & 12.61 & 11.21 & 1.22 & 1.15 \\
\hline $\mathrm{SrO}$ & 0.27 & 0.32 & bdl & bdl \\
\hline $\mathrm{BaO}$ & 0.39 & 0.35 & 0.15 & 0.15 \\
\hline $\mathrm{Na}_{2} \mathrm{O}$ & 0.31 & 0.18 & 0.13 & 0.17 \\
\hline $\mathrm{K}_{2} \mathrm{O}$ & 0.16 & 0.15 & 0.03 & bdl \\
\hline $\mathrm{F}$ & 2.87 & 5.31 & 1.16 & 1.00 \\
\hline Total & 91.46 & 91.00 & 94.68 & 95.28 \\
\hline $\mathrm{F}$ & 2.87 & 5.31 & 1.16 & 1.00 \\
\hline$\Sigma \mathrm{REE}_{2} \mathrm{O}_{3}$ & 20.08 & 22.00 & 2.59 & 3.27 \\
\hline \multicolumn{5}{|c|}{ Calculated formulae (apfu)* } \\
\hline $\mathrm{Ca}$ & 1.125 & 1.541 & 3.867 & 3.878 \\
\hline $\mathrm{Sr}$ & 0.029 & 0.035 & 0.064 & 0.064 \\
\hline $\mathrm{Na}$ & 0.110 & 0.067 & 0.038 & 0.050 \\
\hline $\mathrm{K}$ & 0.037 & 0.035 & 0.006 & 0.000 \\
\hline $\mathrm{Ba}$ & 0.028 & 0.026 & 0.009 & 0.009 \\
\hline $\mathrm{Y}$ & 0.000 & 0.000 & 0.000 & 0.000 \\
\hline $\mathrm{La}$ & 0.325 & 0.355 & 0.011 & 0.020 \\
\hline $\mathrm{Ce}$ & 0.732 & 0.830 & 0.094 & 0.103 \\
\hline $\operatorname{Pr}$ & 0.066 & 0.059 & 0.009 & 0.012 \\
\hline $\mathrm{Nd}$ & 0.196 & 0.259 & 0.029 & 0.045 \\
\hline $\mathrm{Sm}$ & 0.018 & 0.021 & 0.000 & 0.000 \\
\hline $\mathrm{Eu}$ & 0.000 & 0.000 & 0.000 & 0.000 \\
\hline $\mathrm{Gd}$ & 0.019 & 0.000 & 0.000 & 0.000 \\
\hline Th & 0.023 & 0.026 & 0.011 & 0.011 \\
\hline Sum A & 2.709 & 3.255 & 4.138 & 4.192 \\
\hline $\mathrm{Fe}^{2+}$ & 1.000 & 1.000 & 0.154 & 0.145 \\
\hline Mn & 0.000 & 0.000 & 0.000 & 0.000 \\
\hline $\mathrm{Mg}$ & 0.000 & 0.000 & 0.005 & 0.005 \\
\hline
\end{tabular}

Table 3 (continued)

\begin{tabular}{lllll}
\hline $\begin{array}{l}\text { Sample } \\
\text { Analysis }\end{array}$ & Kr-6-19 & Kr-6-19 & Kr-6-19 & Kr-6-19 \\
\hline Sum B & 1.000 & 1.000 & 0.159 & 64 \\
$\mathrm{Fe}^{2+}$ & 0.953 & 0.781 & 0.000 & 0.150 \\
$\mathrm{Mn}$ & 0.069 & 0.078 & 0.000 & 0.000 \\
$\mathrm{Mg}$ & 0.461 & 0.393 & 0.000 & 0.000 \\
$\mathrm{Al}$ & 0.908 & 0.764 & 0.874 & 0.894 \\
$\mathrm{~V}$ & 0.049 & 0.035 & 0.019 & 0.029 \\
$\mathrm{Sc}$ & 0.239 & 0.257 & 0.021 & 0.025 \\
$\mathrm{Zr}$ & 0.107 & 0.106 & 0.023 & 0.029 \\
$\mathrm{Nb}$ & 0.000 & 0.000 & 0.000 & 0.000 \\
$\mathrm{Ta}$ & 0.007 & 0.006 & 0.000 & 0.000 \\
$\mathrm{Ti}$ & 0.128 & 0.075 & 1.322 & 1.260 \\
Sum C & 2.922 & 2.494 & 2.259 & 2.238 \\
Ti $(=\mathbf{D})$ & 2.000 & 2.000 & 2.000 & 2.000 \\
Si $(=\mathbf{T})$ & 4.949 & 4.898 & 4.791 & 4.790 \\
$\mathbf{\Sigma}$ cations & 13.58 & 13.65 & 13.35 & 13.37 \\
\hline${ }^{*}$ Calculated based on 4 O atoms per formula unit. FeO*, all Fe as \\
Fe ${ }^{2+}$ bdl, below detection limit
\end{tabular}

$\mathrm{Fe}^{2+}$. bdl, below detection limit

(2014) suggested that allanite growth is favored by relatively high oxidizing conditions.

\section{Structural breakdown of perrierite}

It appears that the Mazury Complex CGM have recorded intermediate stages in the alteration of a CGM to a titanitelike phase. We have carried out detailed EPMA and EBSD analyses in an attempt to determine the compositional and structural nature of the titanite-like phase. Five compositional profiles were made across the crystal in sample Kr-6-41 shown in Fig. 7a; the data are given in Table S2. Compositional variations along one profile, as an example (profile E-F), are shown in Fig. 8. The crystal has been divided into three zones, the bright, transitional and dark zones. The bright zone is slightly altered perrierite-(Ce), brighter spots pointing to local concentrations of Ti (Fig. 9). Within the transitional zone, there are increases in the contents of $\mathrm{SiO}_{2}, \mathrm{TiO}_{2}$, and $\mathrm{ThO}_{2}$, and decreases in $\mathrm{FeO}^{*}, \mathrm{SrO}$, $\mathrm{BaO}$, which are continued into the dark zone. Most marked is the sharp drop into the dark zone of LREE ( $\mathrm{La}-\mathrm{Eu})$, from $\Sigma \mathrm{REE}_{2} \mathrm{O}_{3} \geq 35 \mathrm{wt} \%$ to $<5 \mathrm{wt} \%$. While the most Ti-rich analyses have a titanite-like composition, there is a notable gap between 5 and $14 \mathrm{wt} \% \mathrm{CaO}$, the gap coinciding precisely with the transition zone. Thus the transition from perrierite(Ce) to titanite-like compositions was sharp. The gap does not exist in all crystals in the data set; for example, there is a continuous series of compositions in sample $\mathrm{Kr}-6-19$ (Table S1). Judging from the patchiness of the partially altered perrierite-(Ce), the alteration reached different parts 

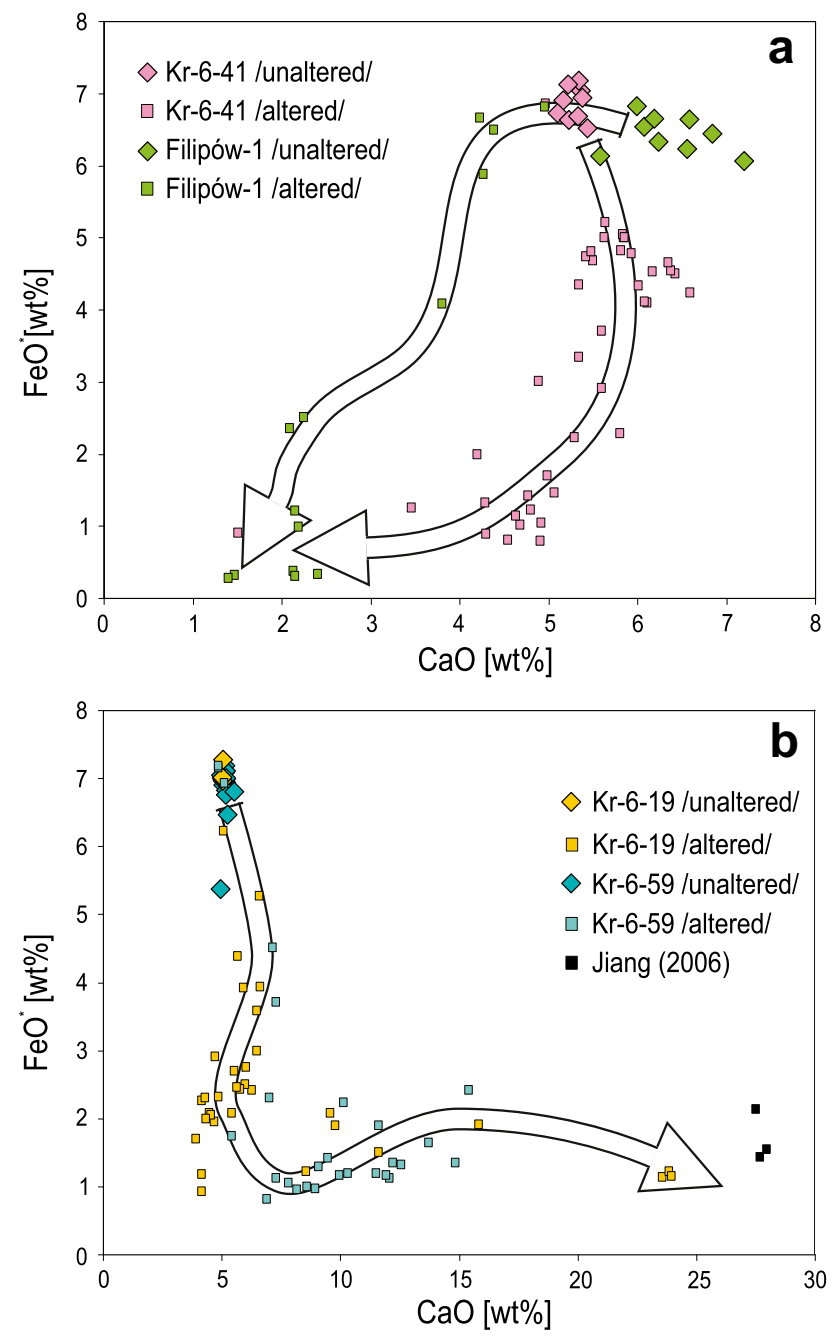

Fig. 6 a Two Ca-Fe depletion trends exemplified by samples $\mathrm{Kr}-6-41$ and Filipów-1. b The Ca-Ti enrichment trend as shown by Kr-6-19 and $\mathrm{Kr}-6-59$. Data from Tables S1 and S2. Also plotted is the composition of titanite formed by breakdown of chevkinite-(Ce) in the Shuiquangou syenitic intrusion, China (Jiang 2006)

of the crystals at different times. The breakdown of perrierite-(Ce) was clearly a very variable process. Furthermore, the different alteration trends shown on Fig. 6 may indicate that fluids of different composition affected the rocks at different times.

The crystal shown in Fig. $7 \mathrm{~b}$ is of particular interest because it provides evidence of the nature of the hydrothermal fluids promoting the alteration to the titanite-like phase, the presence of REE-carbonates and pyrrhotite points to the presence of $\mathrm{CO}_{2}$ and $\mathrm{S}$ in the fluids.

A representative electron backscatter pattern of perrierite(Ce), crystallizing in $P 2_{1} / c$ (a standard setting of commonly used, $P 2_{1} / a$, the difference is only in the order of the crystallographic axes, both choices are symmetrically equivalent) is presented together with indexed, simulated pattern in Fig. 12.
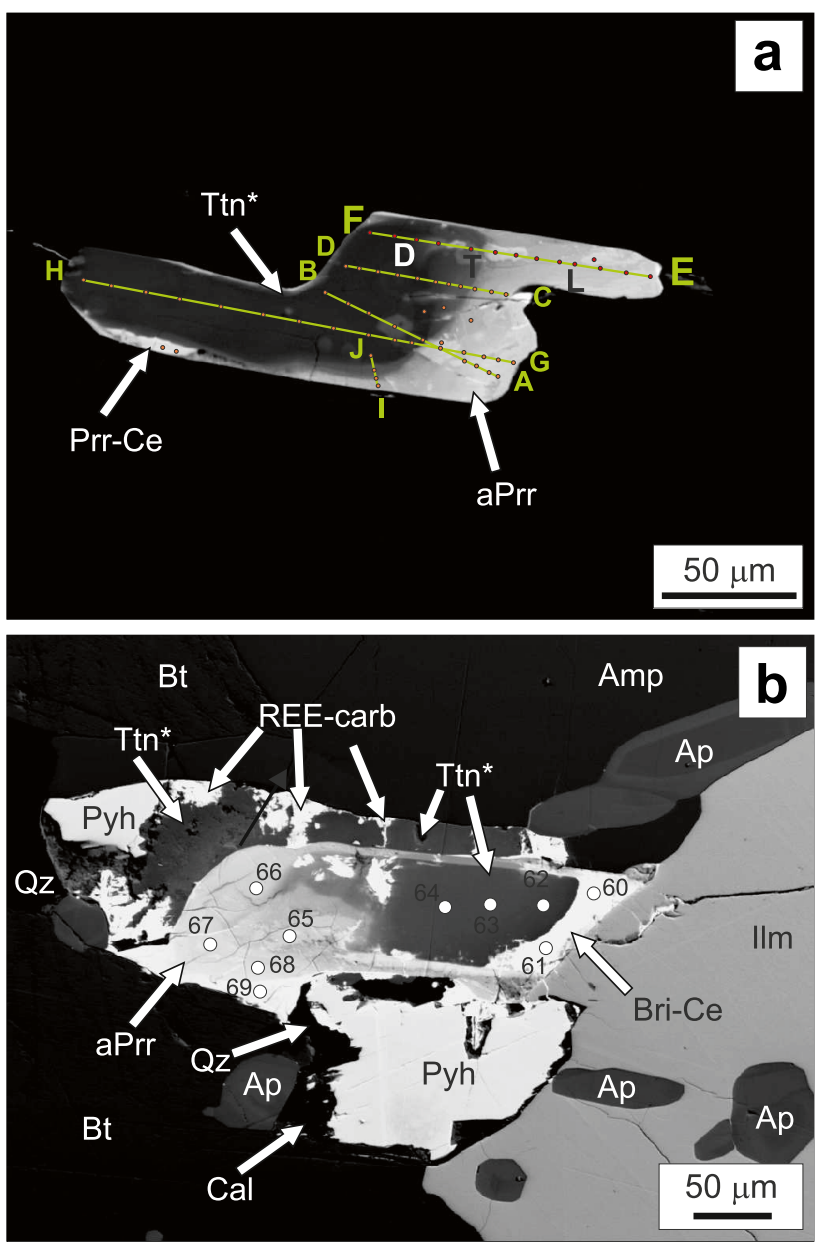

Fig. 7 a BSE image of perrierite-(Ce) showing locations of compositional profiles (sample $\mathrm{Kr}-6-41$; analyses in Table S2). b BSE image of sample $\mathrm{Kr}-6-19$, showing partially replaced perrierite-(Ce), the titanite-like phase ( $\left.\mathrm{Ttn}^{*}\right)$, pyrrhotite (Pyh), REE carbonates (REEcarb) and britholite-(Ce) (Bri-Ce). Amp, amphibole: Bt, biotite: $\mathrm{Cal}$, calcite: Qz, quartz. D - dark, T - transitional, L - light

Compositional data in Fig. 8, between analyses $22-28$ correspond to the crystalline section of perrierite-(Ce) obtained from EBSD (red zone in Fig. 10a). Perrierite-(Ce) breaks down to an amorphous phase of titanite-like composition. Figure 10b shows the crystalline areas in brighter colour. The interior of the analyzed surface, i.e. the titanite-like phase, does not diffract electrons, meaning that it is amorphous.

\section{Discussion}

\section{Crystallization conditions}

The perrierite-bearing rocks from the Mazury Complex crystallized from broadly mafic to trachyandesitic melts. This is consistent with the findings of Macdonald and Belkin 
Fig. 8 Compositional variations along profile $\mathrm{E}-\mathrm{F}$ of crystal from sample $\mathrm{Kr}-6-41$ shown in Fig. 7a (analyses in Table S2)

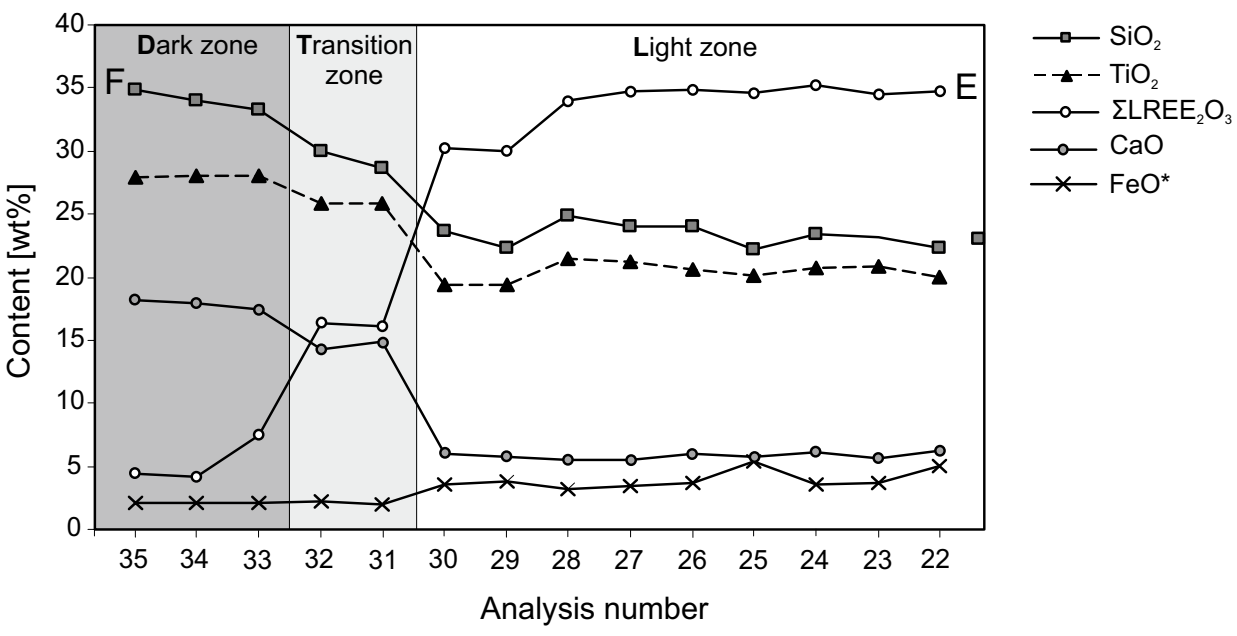

(2002), who showed that in igneous suites perrierite tends to form in rocks of intermediate and mafic composition (Fig. 11) while chevkinite forms in more evolved melts, such as granites, syenites and extrusive equivalents. Information on the P-T crystallization conditions comes from the associated charnockitic rocks. Based on pyroxene compositions, (Bagiński and Krzemińska 2005; Bagiński et al. 2006) estimated that the charnockites crystallized at a maximum range of ca. $850-950{ }^{\circ} \mathrm{C}$ and under variable polybaric pressure conditions. This temperature range is consistent with the likely crystallization temperatures of intermediate melts. Note, however, that the estimates assumed limited thermal influence from the coeval anorthosite bodies, intruded during the same AMCG magmatism stage.

Crystallization of the perrierite- $(\mathrm{Ce})$ in the granulite facies is consistent with the occurrence of dominant $\mathrm{Al}$ in the $\mathrm{C}$ site. Al-dominant perrierite has been reported from several areas of granulitic facies rocks in Antarctica and India (Harley 1994; Hokada 2007; Belkin et al.

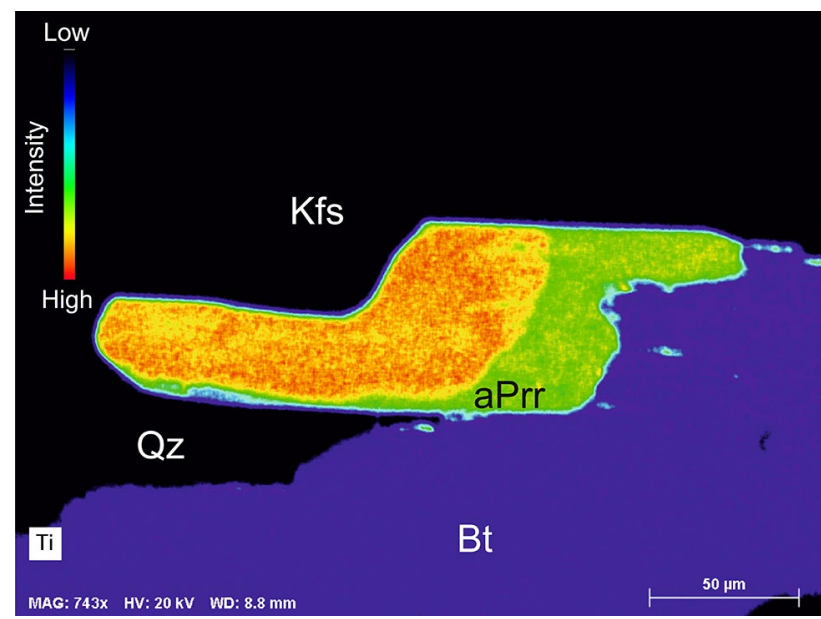

Fig. 9 Ti K $\alpha$ X-ray intensity map for crystal shown in Fig. 7a. The colour range from blue to red indicates increasing concentrations of $\mathrm{Ti}$
2009) (Fig. 4). There is also experimental evidence that high-pressure appears to favour the entry of Al into the CGM structure: Green and Pearson (1988) crystallized Aldominant perrierites-(Ce) from REE-enriched andesitic and rhyolitic melts at $\mathrm{P}=20 \mathrm{kbar}, \mathrm{T}=1050{ }^{\circ} \mathrm{C}$.

\section{Effects of hydrothermal activity}

Studies of the hydrothermal alteration of chevkinite-(Ce) from Russia and Scotland (Bagiński et al. 2015) and Brazil
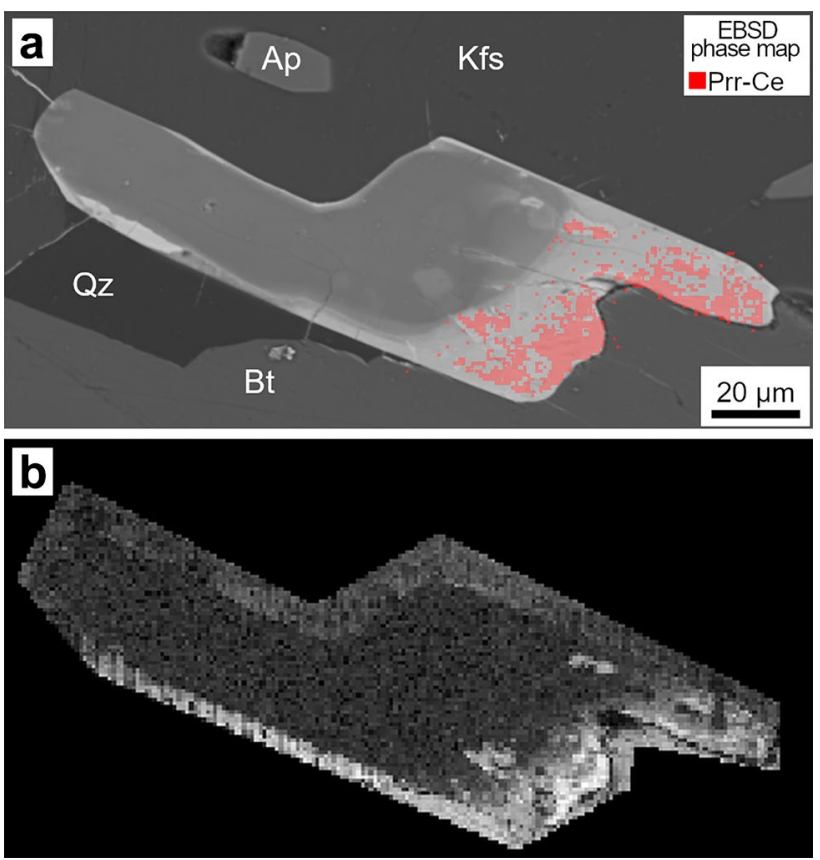

Fig. 10 a BSE image of $\mathrm{Kr}-6-41$ sample with imposed phase map of perrierite-(Ce) from EBSD analysis. b Pattern quality map indicating the size of the analyzed surface where brightness of the pixels reflects the relative quality of the collected diffraction patterns. The internal part of the compositionally titanite-like phase is non-crystalline, showing no diffraction 
Fig. 11 Unaltered perrierite(Ce) in the paragenesis plot of Macdonald and Belkin (2002), slightly modified. Values are plotted in apfu

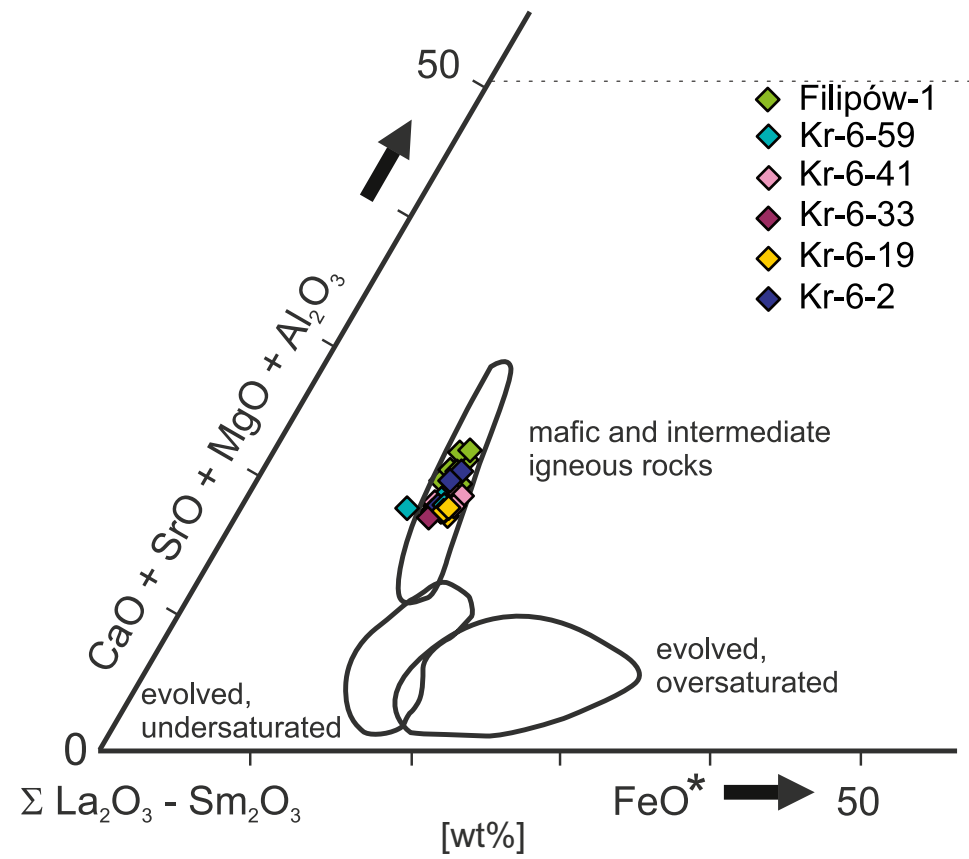

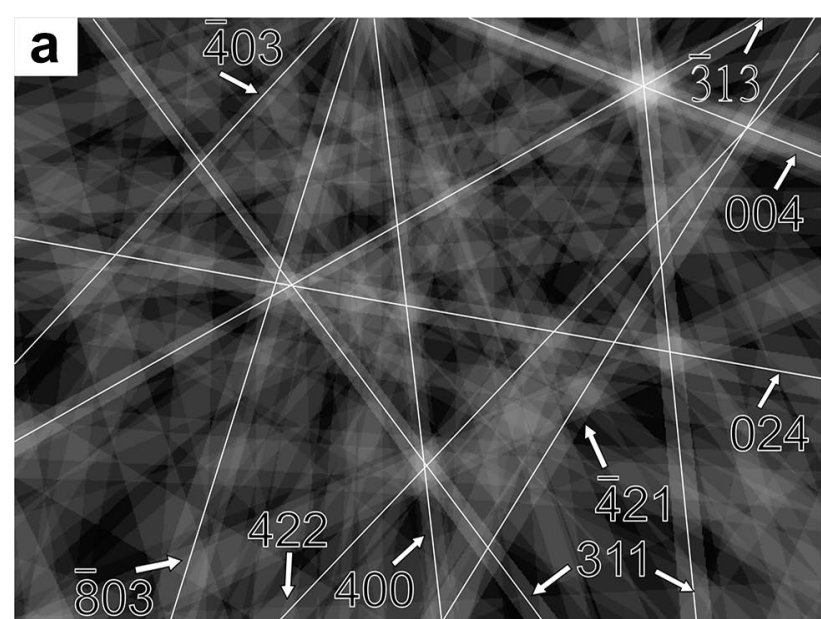

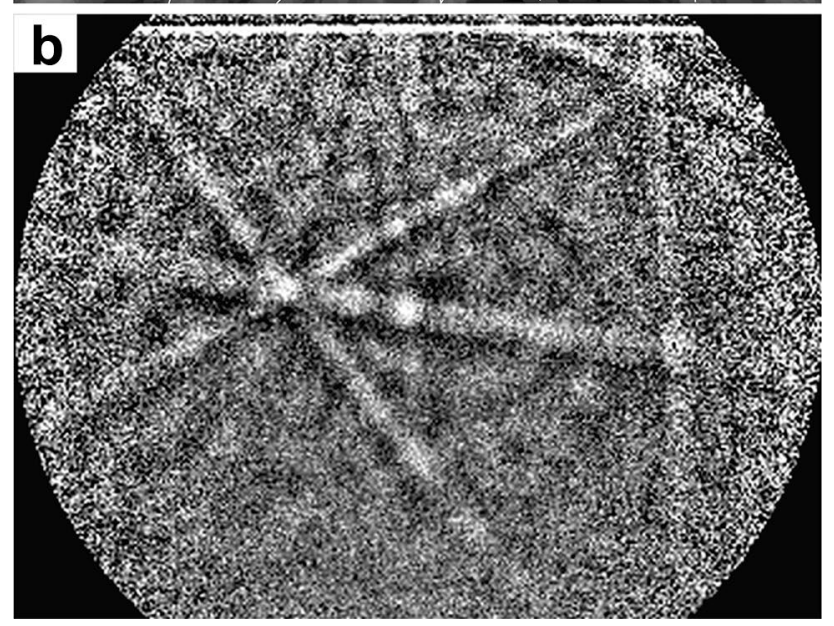

Fig. 12 a Simulated, indexed electron backscatter pattern of perrierite-(Ce). b Corresponding, representative experimental pattern
(Vlach and Gualda 2007) found that progressive alteration led initially to $\mathrm{Ca}$ enrichment at constant $\mathrm{Ti}$ and then to rapid Ca depletion with strong Ti enrichment. REE behaviour was more variable, being enriched in some crystals, depleted in others. The Ca, REE, Si and Fe were removed in the fluid phase. The types of alteration shown in Fig. 6a are, however, broadly similar to that recorded by Bagiński et al. (2015). The second trend involved enrichment in $\mathrm{Ca}$, $\mathrm{Ti}$ and $\mathrm{Si}$ and strong depletion in REE and Y. The breakdown of CGM to a titanite-like phase in a wide range of natural rocks (e.g. gabbroids, syenites, pegmatites and metasomatites) has been recorded by, inter alios, Jiang (2006), Prol-Ledemsa et al. (2012), Macdonald et al. (2015a, b), Bagiński et al. (2016) and Spiridonov et al. (2019). In none of these studies was the identification of the titanite-like phase made on the basis of a structural analysis. The Krasnopol case raises the question as to whether the other examples are truly crystalline.

The alteration sequences and products were highly variable between crystals; it may be inferred that the variations were at least partly related to variable compositions of the hydrothermal fluids. Those described by Macdonald et al. (2015b) and Bagiński et al. (2016) were alkaline and contained significant $\mathrm{CO}_{2}$ and $\mathrm{F}$, whereas those in Macdonald et al. (2015a) were thought to have been acidic, with significant $\mathrm{CO}_{2}$ but poor in $\mathrm{F}$. The crystal shown in Fig. 7b is of particular interest because it provides evidence of the nature of the hydrothermal fluids promoting the alteration at Krasnopol. The presence of REE-carbonates and calcite (Figs. 2f, 7b) shows that the fluids were $\mathrm{CO}_{2}$-bearing, while the pyrrhotite points to a component of S. The high F contents (up to $5 \mathrm{wt} \%$ ) of some altered CGM and its presence 
in the REE-carbonate further suggest that the fluids were F-bearing. We can speculate that the titanite-like phase would eventually have crystallized to titanite. Possibly the temperatures during hydrothermal alteration were simply too low to form it but we note that titanite can form at very low temperatures: in an extreme case, it has been recorded as a result of microbial alteration of volcanic glass (Izawa et al. 2019). Alternatively, it may have been a function of the duration of the alteration episode.

\section{Conclusions}

Perrierite-(Ce), a member of the chevkinite-group of minerals, is present in monzodiorites and granodiorites of the Mesoproterozoic Krasnopol intrusion, formed under granulite facies conditions. Consistent with a high-pressure origin, $\mathrm{Al}$ is dominant at the $\mathrm{C}$ site. The perrierite-(Ce) was extensively altered by hydrothermal fluids, which were $\mathrm{CO}_{2}$ and F-bearing, with a component of $\mathrm{S}$. At least two alteration schemes, involving different element mobilities, have been identified, perhaps indicating the presence of more than phase of alteration. One scheme resulted in an amorphous phase compositionally close to titanite.

Supplementary information The online version contains supplementary material available at https://doi.org/10.1007/s00710-022-00772-4.

Acknowledgements We thank Silvio R.F. Vlach, Adam Pieczka, two anonymous reviewers, and editor Lutz Nasdala for helpful comments on the manuscript. The work was supported through the European Union Operational Programme Innovative Economy, 2007-2013, number POIG.02.02.00-00-025/09 (NanoFun; Cryo-SEM microscopy laboratory). Financial support was provided by the National Science Centre Poland, through grant 2017/26/M/ST10/00407 and project D 501113 01- 1130100.

Open Access This article is licensed under a Creative Commons Attribution 4.0 International License, which permits use, sharing, adaptation, distribution and reproduction in any medium or format, as long as you give appropriate credit to the original author(s) and the source, provide a link to the Creative Commons licence, and indicate if changes were made. The images or other third party material in this article are included in the article's Creative Commons licence, unless indicated otherwise in a credit line to the material. If material is not included in the article's Creative Commons licence and your intended use is not permitted by statutory regulation or exceeds the permitted use, you will need to obtain permission directly from the copyright holder. To view a copy of this licence, visit http://creativecommons.org/licenses/by/4.0/.

\section{References}

Bagiński B, Duchesne JC, Vander Auwera J, Martin H, Wiszniewska J (2001) Petrology and geochemistry of rapakivi-type granites from the crystalline basement of NE Poland. Geol Quart 45:33-52

Bagiński B, Krzemińska E (2005) Various kinds of charnockitic rocks from NE Poland. Mineral Soc Pol-Spec Pap 26:13-17
Bagiński B, Kozłowski A, Krzemińska E (2006) Fluid inclusion studies the only key to estimatethe crystallization conditionsof charnokitic rocks from selected boreholes from NE Poland ? Mineral Pol-Spec Pap 29:83-86

Bagiński B, Macdonald R, Dzierżanowski P, Zozulya D, Kartashov PM (2015) Hydrothermal alteration of chevkinite-group minerals: products and mechanisms. Part 1. Hydration of chevkinite-(Ce). Mineral Mag 79:1019-1037

Bagiński B, Zozulya D, Macdonald R, Kartashov PM, Dzierżanowski $\mathrm{P}$ (2016) Low-temperature hydrothermal alteration of a rare-metal rich quartz-epidote metasomatite from the El'ozero deposit, Kola Peninsula, Russia. Eur J Mineral 28:789-910

Belkin HE, Macdonald R, Grew ES (2009) Chevkinite-group minerals from granulite-facies metamorphic rocks and associated pegmatites of East Antarctica and South India. Mineral Mag 73:149-164

Claesson S, Sundblad K, Ryka W, Moczydłowska M, Reinfrank R (1995) Proterozoic ages from the Precambrian of Poland - results and implications. In: Glebovitsky VA, Kotov AB: MAEGS-9 (eds) Precambrian of Europe. Abstract 21

Dörr W, Belka Z, Marheine D, Schastok J, Valverde-Vaquero P, Wiszniewska J (2002) U-Pb and Ar-Ar geochronology of anorogenic granite magmatism of the Mazury complex NE Poland. Precamb Res 119:101-120

Duchesne JC, Martin H, Bagiński B, Wiszniewska J, Vander Auwera J (2010) The origin of ferroan-potassic A-type granitoids: the case of the hornblende-biotite granite suite of the Mesoproterozoic Mazury complex, northeastern Poland. Can Mineral 48:947-968

Frost BR, Barnes CG, Collins WJ, Arculus RJ, Ellis DJ, Frost CD (2001) A geochemical classification for granitic rocks. J Petrol 42(11):2033-2048

Galanciak J, Bagiński B, Macdonald R, Belkin HE, Kotowski K, Jokubauskas P (2020) Relationships between monazite, apatite and chevkinite-group minerals in the rhyolitic Joe Lott Tuff, Utah, USA. Lithos 354-355, 105349

Green TH, Pearson NJ (1988) Experimental crystallization of chevkinite/ perrierite from REE-enriched silicate liquids at high pressure and temperature. Mineral Mag 52:113-120

Haapala I, Rämö OT (1992) Tectonic setting and origin of the Proterozoic rapakivi granites of southeastern Fennoscandia. Trans Roy Soc Edinburgh: Earth Sci 83:165-171

Haapala I, Rämö OT (1999) Rapakivi granites and related rocks: an introduction. Precamb Res 95:1-7

Haapala I, Rämö OT, Frindt S (2005) Comparison of Proterozoic and Phanerozoic rift-related basaltic-granitic magmatism. Lithos 80:1-32

Harley SL (1994) Mg-Al yttrian zirconolite in a partially melted sapphirine granulite Vestfold Hills, East Antarctica. Mineral Mag 58:259-269

Hokada T (2007) Perrierite in sapphirine-quartz gneiss: geochemical and geochronological features and implications for accessoryphase paragenesis of UHT metamorphism. J Mineral Petrol Sci 102:44-49

Izawa MRW, Bannerjee NR, Shervais JW, Flemming RL, Hetherington CJ, Muehlenbachs K, Schultz C, Das D, Hanan BB (2019) Titanite mineralization of microbial bioalteration textures in Jurassic volcanic glass., Coast Range ophiolite, California. Front Earth Sci 2019. https://doi.org/10.3389/feart.2019.00315

Jiang N (2006) Hydrothermal alteration of chevkinite-(Ce) in the Shuiquangou syenitic intrusion, northern China. Chem Geol 227:100-112

Kubicki S, Ryka W (eds) (1982) Atlas geologiczny podłoża krystalicznego polskiej części platformy wschodnioeuropejskiej. Wydawnictwa Gelogiczne Warszawa

Macdonald R, Belkin HE (2002) Compositional variation in minerals of the chevkinite group. Mineral Mag 66:1075-1098 
Macdonald R, Belkin HE, Wall F, Bagiński B (2009) Compositional variation in the chevkinite group: new data from igneous and metamorphic rocks. Mineral Mag 73:777-796

Macdonald R, Bagiński B, Kartashov PM, Zozulya D, Dzierżanowski P (2015a) Hydrothermal alteration of chevkinite-group minerals. Part 2. Metasomatite from the Keivy massif, Kola Peninsula. Russia. Mineral Mag 79:1039-1059

Macdonald R, Bagiński B, Kartashov PM, Zozulya D, Dzierżanowski P (2015b) Interaction of chevkinite-(Ce) with hydrothermal fluids; evidence from metasomatites of the Haldzan Buragtag massif, Mongolian Altai. Can Mineral 53:1015-1034. https://doi.org/10. 3749/canmin.140002.3

Macdonald R, Bagiński B, Belkin HE, Stachowicz M (2019) Composition, paragenesis and alteration of the chevkinite group of minerals. Am Mineral 104:349-367

Monchoux P, Fontan F, de Parseval P, Martin RF, Wang RC (2006) Igneous albitite dikes in orogenic lherzolites, Western Pyrénées, France: a possible source for corundum and alkali feldspar xenocrysts in basaltic terranes. 1. Mineral Ass Can Mineral 44:817-842

Nagashima M, Armbruster T, Akasak M, Sano-Furukawa A, NishioHamane D, Maisy A, Imaoka T, Nakashima K (2020) Multimethodical study of the $\mathrm{Ti}, \mathrm{Fe}^{2+}$ and $\mathrm{Fe}^{3+}$ distribution in chevkinitesubgroup minerals: X-ray diffraction, neutron diffraction, ${ }^{57} \mathrm{Fe}$ Mössbauer spectroscopy and electron-microprobe analyses. Phys Chem Mineral 47:29

Nejbert K, Bagiński B, Kotowski J, Jokubauskas P, Jurewicz E, Macdonald R (2020) Chevkinite-group minerals in Poland. Acta Geol Pol 70:97-106

Pouchou JL, Pichoir JF (1991) Quantitative analysis of homogeneous or stratified microvolumes applying the model 'PAP.' In: Heinrich KFJ, Newbury DE (eds) Electron Probe Quantification. Plenum Press, New York, 31-75

Prol-Ledemsa R-M, Melgarejo JC, Martin RF (2012) The El Muerto "NYF" granitic pegmatite, Oaxaca, Mexico, and its striking enrichment in allanite-(Ce) and monazite-(Ce). Can Mineral 50:1055-1076

Proshchenko YG (1967) Rare earth minerals from albitites of eastern Siberia. In: Mineralogiya pegmatitov i gidrotermalitov shchelochnykh massivov. Akademii Nauk SSSR, Institut Mineralogii, Geokhimii, Kristallokhimii Redk. Elementov, Moscow, 103-136. (in Russian)

Rämö OT, Haapala I (1995) One hundred years of rapakivi granite. Mineral Petrol 52:129-185

Rickwood PC (1989) Boundary lines within petrologic diagrams which use oxides of major and minor elements. Lithos 22(4):247-263

Ryka W (1982) Prekambryjska Ewolucja Platformy Wschodnioeuropejskiej. Geol Quart 26:257-272

Ryka W (1993) Crystalline basement of Suwalszczyzna (NE Poland). Przeg Geol 41:546-551 (in Polish)

Ryka W, Sawicki L (1980) Aktualny stan badań utworów prekambryjskich w Polsce i kierunki ich rozwoju. Kwart Geol 24(1):89-105

Seifert W, Kramer W (2003) Accessory titanite: an important carrier of zirconium in lamprophyres. Lithos 71:81-98

Shumlyanskyy L, Hawkesworth C, Billström K, Bogdanova S, Mytrokhyn O, Romer R, Dhuime B, Cleasson S, Ernst R, Whitehouse M, Bilan O (2017) The origin of the Palaeoproterozoic AMCG complexes in the Ukrainian shield: New U-Pb ages and $\mathrm{Hf}$ isotopes in zircon. Precamb Res 292:216-239

Skridlaite G, Wiszniewska J, Duchesne JC (2003) Ferro-potassic A-type granites and related rocks in NE Poland and S Lithuania: west of the East European Craton. Precamb Res 124:305-326

Spiridonov EM, Filimonov SV, Semikolennykh ES, Korotayeva NN, Krivitskaya NN (2019) Chevkinite-(Ce) and perrierite-(Ce) in the island arc quartz gabbro-norite-dolerites of the Ayu-Dag intrusion, Rocky Crimea. Proc Russ Mineral Soc 148 (4):61-79. (in Russian)

Stachowicz M, Bagiński B, Welch MD, Kartashov PM, Macdonald R, Balcerzak J, Tyczkowski J, Woźniak K (2019) Cation ordering, valence states, and symmetry breaking in the crystal-chemically complex mineral chevkinite-(Ce): X-ray diffraction and photoelectron spectroscopy studies and mechanisms of $\mathrm{Nb}$ enrichment. Am Mineral 104:595-602

Sun SS, McDonough WF (1989) Chemical and isotopic systematics of oceanic basalts: applications for mantle composition and processes. In: Saunders AD, Norry MJ (eds) Magmatism in the Ocean Basins. Geol Soc, London, Spec Publ 42:313-345

Sundblad K, Mansfeld J, Motuza G, Ahl M, Claesson S (1994) Geology, geochemistry and age of a Cu-Mo-bearing granite at Kabeliai, southern Lithuania. Mineral Petrol 5:43-57

Vlach SRF, Gualda GAR (2007) Allanite and chevkinite in A-type granites and syenites of the Graciosa Province, southern Brazil. Lithos 97(1-2):98-121

Vlach SRF, Gualda GAR, Steele IM, Vilalva FCJ (2014) Chevkinite $\rightarrow$ allanite reaction relationships in silicic rocks. Workshop on accessory minerals, 24-26 September, Warsaw. Book of Abstracts, $44-41$

Vorma A (1976) On the petrochemistry of rapakivi granites with special reference to the Laitila massif, southwestern Finland. Geol Surv Finland Bull 285

Wiszniewska J, Kusiak MA, Krzemińska E, Dörr W, Suzuki K (2007) Mesoproterozoic AMCG granitoids in the Mazury Complex, NE Poland- a geochronological update. In: Kozłowski A, Wiszniewska J (eds) Granitoids in Poland. AM Monograph No 1. Komitet Nauk Mineralogicznych Polskiej Akademii NaukWydział Geologii Uniwersytet Warszawski, 31-39

Wiszniewska J, Krzemińska E, Williams IS, Krzemiński L (2016) AMCG suite in NE Poland; subsequent datings of A-type granitoids on SHRIMP. 8th SHRIMP Workshop, 6-10 September 2016, Granada, Spain, 87-89

Wybraniec S (1999) Transformation and visualization of potential field data. Pol Geol Inst, Spec Pap 1:1-88

Zozulya D, Macdonald R, Bagiński B (2020) REE fractionation during crystallization and alteration of fergusonite-(Y) from $\mathrm{Zr}$-REE-Nbrich late- to post-magmatic products of the Keivy alkali granite complex, NW Russia. Ore Geol Rev 125:103693

Publisher's Note Springer Nature remains neutral with regard to jurisdictional claims in published maps and institutional affiliations. 